\title{
Identifying Ecosystem Services for a Framework of Ecological Importance for Rivers in South East Asia
}

\author{
Peter-John Meynell *, Marc Metzger and Neil Stuart
}

Citation: Meynell, P.-J.; Metzger, M.; Stuart, N. Identifying Ecosystem Services for a Framework of Ecological Importance for Rivers in South East Asia. Water 2021, 13, 1602. https://doi.org/10.3390/w13111602

Academic Editor: Rui Cortes

Received: 1 May 2021

Accepted: 2 June 2021

Published: 6 June 2021

Publisher's Note: MDPI stays neutral with regard to jurisdictional claims in published maps and institutional affiliations.

Copyright: (c) 2021 by the authors. Licensee MDPI, Basel, Switzerland. This article is an open access article distributed under the terms and conditions of the Creative Commons Attribution (CC BY) license (https:// creativecommons.org/licenses/by/ $4.0 /)$.
School of GeoSciences, University of Edinburgh, Edinburgh EH8 9XP, UK; marc.metzger@ed.ac.uk (M.M.); N.Stuart@ed.ac.uk (N.S.)

* Correspondence: peterjohn.meynell@ed.ac.uk; Tel.: +44-07305899537

\begin{abstract}
There are increasing concerns for the ecological health of rivers, and their ability to provide important ecosystem services. Frameworks describing the character and condition of rivers have been developed in many parts of the world but rarely include river ecosystem services. South East Asia is a region with some of the world's great rivers-Mekong, Salween and Ayeyarwady-running through six different countries, but data on river ecological character and condition is patchy and inconsistent. Development pressures on these rivers has never been higher, and ecosystem services may be lost before being described and valued. The development of a framework of ecological importance is envisaged, which maps out the relative contributions of river reaches to a wide range of ecosystem services. This could be a tool for river basin planning and water resource management, baseline information for impact assessment of infrastructure (for example, hydropower and irrigation), and for protecting ecologically important areas. We asked a diverse group of 109 river basin planners, and water and natural resource management professionals in the region whether a framework of ecological importance would support their activities, and which river ecosystem services are most important to be assessed. Our findings allow prioritisation of river ecosystem services to be assessed and mapped according to importance in different river reaches and sub-basins within the region. The locations of ranked threats and pressures on the river systems allow indication of river health and integrity in these sub-basins. We consider the feasibility of measuring ecosystem services and pressures through the identification of appropriate indicators, methods, and availability of global, regional, and national data.
\end{abstract}

Keywords: Greater Mekong region; rivers; ecosystem services; river reach mapping

\section{Introduction}

In many parts of the world, there are increasing concerns about the ecological status and health of rivers, and their capacity to provide different ecosystem services. The Ramsar Convention estimates that at least 64 percent of wetlands across the globe has been lost since 1900 [1]. The European Environment Agency considers that only 40 percent of Europe's waterways are in good ecological health [2]. Thirty-six percent of the 15,000 species of freshwater fish are now classified as threatened on the International Union for the Conservation of Nature's (IUCN) Red list [3]. A recent study to identify free-flowing rivers of the world concluded that $48 \%$ of all river reaches in the global HydroSHEDS database are impaired by diminished river connectivity; of the large rivers in the Greater Mekong region, only the Ayeyarwady and the Salween remain free-flowing [4].

Mainland South East Asia contains some of the great transboundary rivers of the world, notably the Mekong, Red River, Ayeyarwady, and Salween, rising in the mountains in China, passing through six countries, and ending in major delta systems (see Figure 1). These rivers are under increasing development pressures with rising populations and urbanisation [5,6], to such an extent that there is a concern-expressed, for example, in strategic and cumulative environmental assessments of hydropower development-that 
many of the rich riverine ecosystems are being lost or damaged without really knowing and valuing the services they provide [7-9].

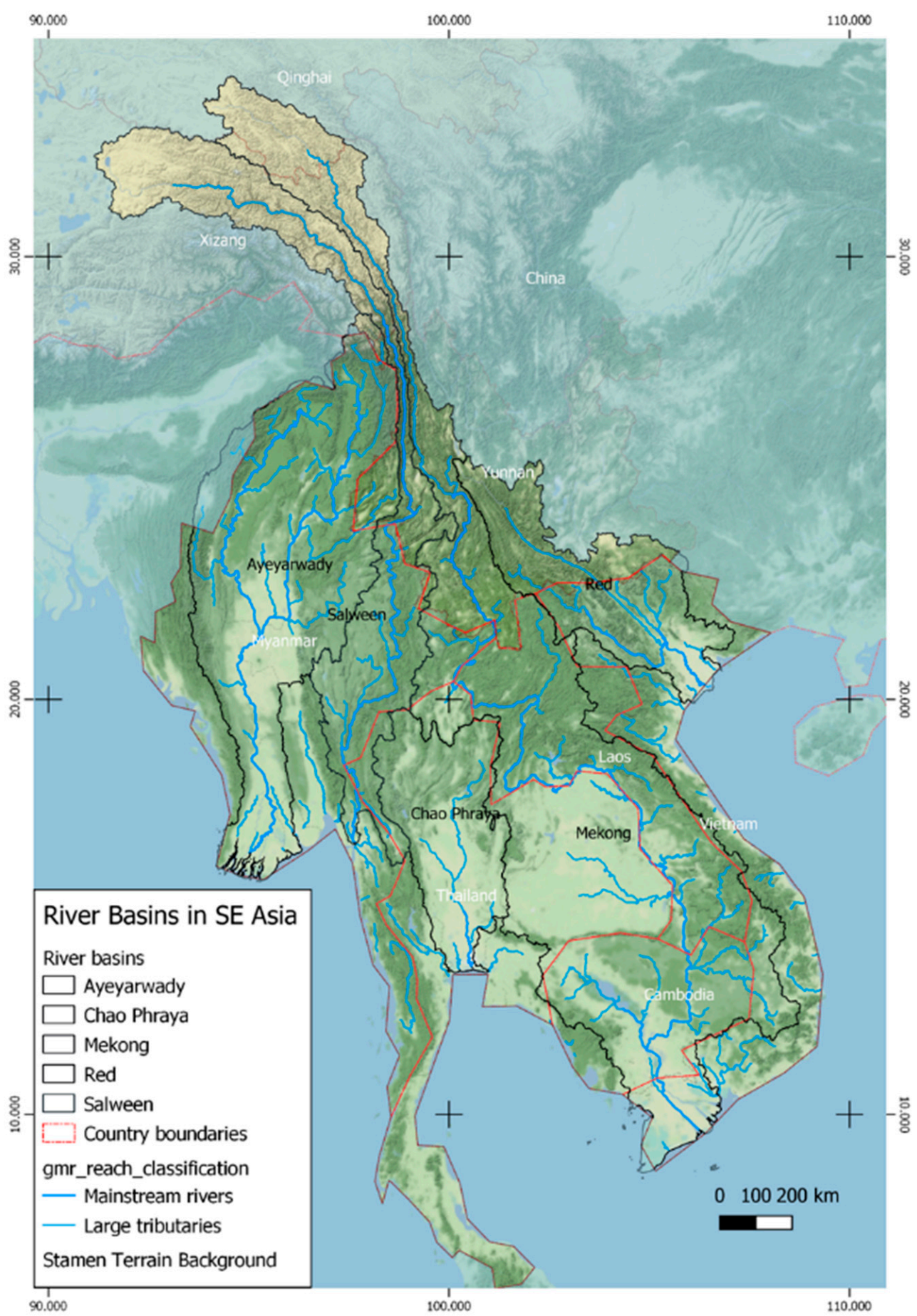

Figure 1. Major river basins in South East Asia.

A recent United Nations (UN) progress report on Sustainable Development Goal No. 6 [10] has estimated that, under Indicator 6.6.1 of Target 6.6-By 2020, protect and restore water related ecosystems, including mountains, forests, wetlands, rivers, aquifers and lakes-one-fifth of the world's river basins are experiencing rapid changes in the area covered by surface water and South East Asia is amongst the regions with the highest rate of change with an overall negative trend (Thailand 11\%, Myanmar 18\%, Viet Nam 40\%, Laos 30\%, Cambodia 27\%). The Mekong River Commission's 2018 State of the Basin 
Report, published every five years also uses these SDG Indicators and shows that changing water-related ecosystems is of considerable concern and urgent action is needed, noting that the "decline in wetlands continues and the quality of fisheries resources is reduced. Deforestation appears now to being reversed in some areas. Mainstream flow regime changes induced by new storages threaten ecosystems" [11].

Over recent decades, various approaches have been made to understand how riverine ecosystems function and anthropogenic actions and developments can degrade the structure and functions of rivers, for example, through pollution, river channelisation, diversion and damming; with this understanding, the river ecosystems can be managed and protected more effectively. A range of systems and frameworks for riverine ecosystem management have been developed from principles of biotic integrity, ecosystem health, and ecological resilience [12]. They have depended upon survey and monitoring of physicochemical assessments of river flows and water quality, and bioassessment. Often, these result in a colour-coded mapping of water quality or river health status of river reaches in the network.

These frameworks are primarily aimed at mapping change in status-either degradation or loss, or for planning improvements. For example, the aim of the European Commission's Water Framework Directive is "to achieve "good ecological status" and "good surface water chemical status" in all bodies of surface water by 2015". Guidance Document 13 provides the indicators and assessment measures for classifying different types of freshwater into ecological condition classes. The indicators are grouped into biological, hydro-morphological, and physico-chemical elements. Monitored measurements are compared to reference conditions and thresholds [13].

In Australia, the National River Health Programme (NRHP) has developed a nationally standardised method of assessing river health-Australian River Assessment Scheme (AUSRIVAS), which is a rapid bioassessment method utilizing macroinvertebrates as sensitive and consistent long-term indicators of in-stream health. The Tasmanian assessment and mapping program - the Conservation of Freshwater Ecosystem Values (CFEV)—assessed the conservation management priorities of all freshwater ecosystems throughout the state. It used existing environmental data to identify where aquatic values exist and their overall priority for conservation management. River sections in the drainage network between confluences are classified according to fluvial geomorphic types, hydrological region, and different biotic assemblages. The condition of each river section is assessed for its naturalness, and its representativeness compared to other river reaches of high degree of naturalness. Distinctiveness is assessed from the presence of special values, for example, rare and threatened species, priority flora communities, and geomorphic features [14].

The Strategic Water Source Areas of South Africa originally mapped by the National Freshwater Ecosystem Project [15] have been used to develop an Atlas of Freshwater Ecosystem Priority Areas. This mapped geo-spatial data according to the selected sub-catchments, including river and wetland ecosystem types, priority estuaries, fish sanctuaries, other species data (frogs, waterbirds), high water yield areas, and high groundwater recharge areas. It quantified and mapped the major pressures upon riverine freshwater ecosystems as flow alteration, water pollution, destruction or degradation of natural habitat, invasive species, and climate change [16].

There are few examples of systems that have an ecosystem service focus or classified different riverine ecological features or assets. In reviewing the assessment of ecosystem services for managing riverine ecosystems, Böck, Polt, and Schülting note that although there have been many research articles on ecosystem services, the application of their management in practice has lagged behind research [17]. This gap between research and practice is illustrated by the absence of policy guidance for defining, measuring, and valuing ecosystem services, and comprehensive systems for river networks have not been developed [18].

Transboundary river basin management is more challenging than for rivers flowing through one country. Schmeier and Vogel, reviewing transboundary river basin manage- 
ment, consider that the challenges in the design and implementation of joint monitoring programmes and networks and sharing of data are largely due to data gaps and inconsistency, dataset incompatibility, and a lack of willingness among riparian states in a basin to share data and information [19]. Mechanisms in the Greater Mekong region for basin planning and sharing of data, especially hydrological and flow information, are complex and may be restrictive [20]. Even if the data is available from all countries in a river basin, there are issues of compatibility between the different countries, for example, census data and in land use and forest cover categories.

The Mekong River Commission (MRC) was established in 1995 and has been preparing basin plans since 2001 for the four countries of Lower Mekong Basin (Cambodia, Lao PDR, Thailand, and Viet Nam), most recently the Strategic Plan 2021-2025 [21,22]. They have been monitoring conditions on the mainstem and some major tributaries [23,24]. The MRC is a scientific organization providing objective technical advice as a regional platform for water diplomacy; it is not a regulatory body for the management of water resources [25]. River basin planning in the Ayeyarwady, albeit lying mainly in Myanmar, only started within the last five years [26] and the Salween, rising in the Himalayas and forming the boundary between Myanmar and Thailand, is still relatively un-surveyed [27]. The Red River Basin Organisation in Vietnam was established in the 2007, but the experience highlighted the fact that the 25 provinces had few issues in common, let alone wider transboundary issues [28].

The gaps and patchiness of hydrological, ecological, and river health data makes the development of a coherent classification and condition framework for the rivers of South East Asia more challenging than in regions where such data has been collected for several decades. Although the Mekong River Commission has been monitoring the water quality and ecological health status of the Mekong mainstem and a few major tributaries for over a decade and recently developed an indicator framework for managing the river basin [29], these have not been applied on a river reach basis across all the tributaries and sub-basins.

A comprehensive system of geospatial analysis of river ecosystem services for assessing the ecological importance of the river reaches or sub-basins across the Greater Mekong region has not yet been developed. Ecological importance can be assessed from river reach contributions to the different ecosystem functions and services across a basin. Making such analysis spatially explicit allows a more direct connection of the services to the land use within the basin, the river resources, and the populations using them. The full range of river ecosystem services as proposed by the Millennium Ecosystem Assessment-Provisioning, Regulating, Supporting and Cultural services [30]— can be used as indicators of river ecological importance. The mapping of man-made threats and pressures can be used to indicate loss of ecosystem integrity and potential depletion of services. A framework based upon ecosystem services recognizes that the values of these services differ between river reaches and sub-basins, and will be determined by the geomorphology, hydrology, physico-chemical characteristics, and biological assemblages, and the communities and people that use and depend upon them.

A river ecological importance framework offers many potential areas of application [17]; it can be used by river basin planners, water and natural resource users and managers to identify and manage impacts of developments on the river. It can enable identification of priority reaches experiencing major pressures and other reaches offering economic opportunities. It can facilitate more informed evaluation and balancing of development priorities and recognition of potential impacts, based on unified river reach or sub-basin data. It complements terrestrial conservation assessments by prioritisation of river reaches for protection. By applying the framework at a river reach or small sub-basin level, the tendency to generalise values and impacts may be avoided, allowing greater analytical sensitivity.

For it to be applied consistently and have credibility across river basins and countries, the river ecological importance framework needs to be developed in consultation with institutions and stakeholders who may provide the underlying information and monitoring 
data and who would be potential users of the framework. The aim of this study was to understand whether an ecological importance framework could help in planning and management of rivers in South East Asia. Specifically, we wanted to understand (1) the user needs of the framework, (2) the ecosystem services that should be included, and 3) the most important threats and pressures on these ecosystem services and the river systems.

As a first step towards creating this new approach, we interviewed 109 senior river basin, water and natural resource planners and managers, and academics active in the Greater Mekong region to understand common needs for a system of geospatial analysis of river ecosystem services and to reflect how it could be designed. Interviewees were selected because they represented a broad range of potential users of the framework of river ecosystem services from different countries, sectors, and organisations within the region. A structured questionnaire was used to identify the perceived needs and uses for such a framework and to prioritise the river ecosystem services that should be included in the framework, appropriate to the rivers of the Greater Mekong region. Respondents were also asked to prioritise the threats and pressures from human activities affecting the health of these rivers. Discussions focussed on identifying indicators, methods of measurement, and data sources for developing the framework.

This paper presents the findings from these stakeholder interviews. We are able to confirm a general support for the development of a riverine ecosystem service framework, with agreement on the potential uses amongst the stakeholders. We have been able to identify which of the different ecosystem services are considered to be most relevant for South East Asian rivers to be measured and mapped in the proposed framework. Preliminary consideration of the indicators and methods of measurement of the ecosystem services has allowed us to identify those that will be feasible for populating the river reach networks.

\section{Materials and Methods}

\subsection{Identification of Stakeholders}

A long list of potential organisations that would have an interest in using a framework of ecological importance of rivers in South East Asia (SEA) was drawn up. Stakeholders were identified based on personal networks developed over 20 years' experience in the region. A set of selection criteria ensured diverse representation. We aimed to interview at least five persons from each of the SEA countries-China, Myanmar, Lao PDR, Thailand, Cambodia, and Viet Nam; at least five persons from relevant government ministries and research institutes and representatives of river basin organisations, especially the Mekong River Commission and National Mekong Committees. We also aimed to interview representatives of international Non-Governmental Organisations (INGOs) working on river related issues in South East Asia, and academic institutions from the region, especially the Mekong Wetland Universities Network, and at least five international researchers and consultants working on river related issues covering water uses such as hydropower, irrigation, fisheries, navigation, and river-based livelihoods. Appendix A lists the organisations and individuals consulted.

\subsection{Stakeholder Interviews}

One hundred and nine interviews were conducted face to face or occasionally by phone. Interviewees were asked to respond out of their own experience rather than representing the views of their organisations, with their responses treated anonymously. Responses to the questions were collected electronically, entering the data on a prepared "ona" data collection form on a tablet (https: / / company.ona.io/, accessed on 23 September 2019), which allows a direct download of all consolidated data in excel format.

The questionnaire (shown in Appendix B) was structured into four parts:

Part 1: Questions about the respondent-countries and rivers in South East Asia worked on, current organisation, position within the organisation, length of time within 
organisation, length of time working on river-related issues, main disciplines or sectors worked in.

Part 2: Questions about the need for and usefulness of a framework of ecological importance, requesting a scoring of 9 suggested uses for the framework.

Part 3: Questions scoring between 10 and 16 ecosystem services amongst each of Provisioning, Regulating, Supporting, and Cultural services to indicate the importance of their inclusion in a framework.

Part 4: Questions scoring 19 different threats and pressures from human activities upon the rivers.

Although the interviews were structured, there was ample opportunity for the respondents to suggest additional uses, services, or threats, and for discussion about indicators, methods of measurement, and data sources. Many of the interviews were recorded with permission, for later review and confirmation of the notes of the discussions taken.

\subsection{Uses for a Framework of River Ecosystem Services}

The second part of the questionnaire considered the need and usefulness of a framework of river ecological importance and what this framework might be used for. They were first asked if the absence of such a framework or system had ever restricted their work. They were then provided with the examples of uses (Table 1), asked to score them on the "High", "Medium", "Low", "Don't Know" scale and to suggest other uses.

Table 1. Examples of uses for framework of river ecosystem services.

\begin{tabular}{l}
\hline Usefulness of Ecological Importance System of Rivers \\
\hline Preparation of river basin profiles \\
\hline IWRM and Integrate River Basin Management studies \\
\hline Providing biophysical evidence defining environmental assets \\
\hline Understanding the ecological character and habitats of rivers \\
\hline Identifying parts of rivers for protection because of their ecological importance \\
\hline $\begin{array}{l}\text { Identifying parts of rivers that may be impacted by development and develop } \\
\text { mitigation measures }\end{array}$ \\
\hline Fisheries management and regulation \\
\hline Locating and planning hydropower, agriculture or industrial infrastructure \\
\hline For assessing environmental and social impacts (EIA, strategic, and cumulative impact studies \\
\hline
\end{tabular}

\subsection{Prioritising Ecosystem Services of Rivers}

In the third part of the questionnaire, respondents were asked to score the different ecosystem services provided by rivers on the same "High", "Medium", "Low", "Don't Know" or "Not applicable" scale according to their view of importance to be included in a framework. Ecosystem services were listed under the four groups-provisioning, regulating, supporting, and cultural, as shown in Table 2. This list of ecosystem services was developed from the Millennium Ecosystem Assessment categories for wetlands and water [30] and applied in subsequent valuations of wetland ecosystem services [31,32]. A follow-up question after each of these groups of ecosystem services allowed free discussion about ways of measuring that group of services.

\subsection{Prioritising Human Threats and Pressures}

The fourth section in the questionnaire covered the human threats and pressures upon rivers and their ecosystem services shown in Table 3. Respondents were invited to score these on the same "High", "Medium", "Low", "Don't Know", or "Not applicable" scale according to their view of their importance in affecting river health in the Greater 
Mekong region. A follow-up question allowed free discussion about ways of measuring and mapping the threats and pressures.

Table 2. Lists of ecosystem services to be prioritised in the semi-structured questionnaire.

\begin{tabular}{|c|c|c|c|}
\hline Provisioning & Regulating & Supporting & Cultural \\
\hline Water Supply & Flows & Biodiversity & Land use \\
\hline $\begin{array}{ll}\text { - } & \text { Rural water supply } \\
\text { - } & \text { Urban water supply } \\
\text { - } & \text { Water for livestock } \\
\text { - } & \text { Irrigation water } \\
\text { - } & \text { Industrial water supply }\end{array}$ & $\begin{array}{ll}- & \text { Surface water sources } \\
\text { - } & \text { Ground water recharge } \\
\text { - } & \text { Ground water discharge }\end{array}$ & $\begin{array}{ll}\text { - } & \text { Fish } \\
\text { Other aquatic animals } \\
\text { and plants } \\
\text { - } \quad \text { Water birds and mammals } \\
\text { Rare, threatened or } \\
\text { endemic species }\end{array}$ & $\begin{array}{l}\text { - } \quad \text { Protected areas } \\
\text { Political and } \\
\text { administrative boundaries }\end{array}$ \\
\hline
\end{tabular}

\begin{tabular}{|c|c|c|c|}
\hline Food & Water quality & Habitats & Values \\
\hline $\begin{array}{l}\text { - Fish production, } \\
\text { capture fisheries } \\
\text { Aquaculture } \\
\text { - Wild foods, NTFPs (river } \\
\text { weed, other aquatic } \\
\text { animals) } \\
\text { - Riverbank gardens }\end{array}$ & $\begin{array}{ll}\text { - } & \text { Maintaining water quality } \\
& \text { Waste water } \\
& \text { purification } \\
\text { - } & \text { Water-borne disease } \\
& \text { regulation } \\
\text { - } & \text { Pest and invasive } \\
\text { species regulation }\end{array}$ & $\begin{array}{ll}\text { - } & \text { Habitats for spawning } \\
\text { and growing } \\
\text { - }\end{array}$ & $\begin{array}{l}\text { - } \quad \text { Spiritual and religious } \\
\text { values of rivers } \\
\text { - } \\
\text { Aesthetic values-landscape } \\
\text { contribution } \\
\text { Locational } \\
\text { value-communities near } \\
\text { confluences } \\
\text { - Cultural values-e.g., } \\
\text { festivals, boat racing }\end{array}$ \\
\hline Energy \& mining & Erosion, sediment transport & Ecosystem connectivity & Transport \\
\hline $\begin{array}{ll}- & \text { Hydropower } \\
- & \text { Sand and gravel }\end{array}$ & $\begin{array}{ll}- & \text { Source of sediment } \\
- & \text { Sediment deposition }\end{array}$ & $\begin{array}{ll}\text { - } & \text { Fish migration routes } \\
\text { - } & \text { Connectivity }\end{array}$ & - $\quad$ Navigation \\
\hline Fuel and fibre & Climate and air quality & Nutrients/productivity & Recreation and research \\
\hline $\begin{array}{ll}\text { - } & \text { Timber from aquatic and } \\
\text { riverbank trees and plants } \\
\text { - } & \text { Fibre from aquatic plants } \\
\text { (water hyacinth, reeds etc.) } \\
\text { - } \quad \text { Floating wood (fuel wood) }\end{array}$ & $\begin{array}{ll}\text { - } & \text { Local climate } \\
\text { - } & \text { regulation/moderation } \\
\text { - } & \text { Maintaining air quality }\end{array}$ & 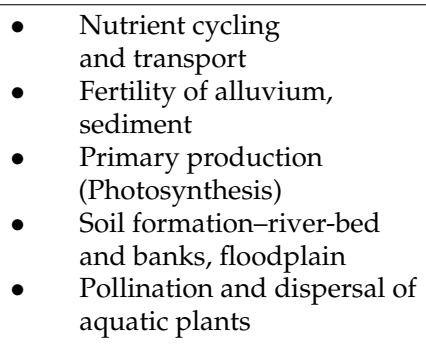 & $\begin{array}{ll}- & \text { Education and research } \\
- & \text { Recreation } \\
- & \text { Ecotourism }\end{array}$ \\
\hline Genetic and medical & Natural hazard regulation & & \\
\hline $\begin{array}{ll} & \text { Genetic resources } \\
\text { - } & \text { Biochemicals, natural } \\
\text { medicines \& } \\
\text { pharmaceuticals }\end{array}$ & $\begin{array}{ll}- & \text { Flash flood risks } \\
- & \text { Dispersion of flood waters } \\
- & \text { Water storage for drought } \\
& \text { risk reduction }\end{array}$ & & \\
\hline
\end{tabular}

Table 3. List of human threats and pressures upon river ecosystems to be prioritised in a semi-structured questionnaire.

Threats and Pressures

\section{Natural Resource Use}

Fishing pressures

\section{Flow changes}

- Changes in seasonal flows

- Changes in daily flows and water levels

\section{Land use change in the catchment}

- Deforestation

- $\quad$ Agriculture conversion

\section{Infrastructure}

- $\quad$ Barriers-weirs, dams and barrages

- Bank protection infrastructure

- Flood protection infrastructure

- Road, bridge and rail construction

- Navigation pressures-oil pollution, bank erosion

- Sand and gravel extraction

- $\quad$ Alluvial gold mining

\section{Water abstraction and storage}

- Reservoirs for irrigation, water supply, hydropower

- Ground water abstraction

\section{Water pollution}

\section{- Urban run-off}

- Industrial waste water discharge

- $\quad$ Sewage discharge

- $\quad$ Solid waste disposal, plastics etc.

- Agricultural run-off, fertilisers, agrochemicals 


\subsection{Analysis of Responses}

The analysis of the responses aims to identify the priority ecosystem services that should be included in a framework of river ecological importance. Preference scores and ranking of ecosystem services and threats was carried out by averaging the weighted numbers of responses of High, Medium, and Low for each service or threat (weighted as follows: High $\times 3$, Medium $\times 2$, Low $\times 1$, Not useful/not known $\times 0$ ).

It was not possible to fully disaggregate the responses by country or river basin worked in or by job type and sector, because many of the respondents had worked in several countries and river basins and had noted several job types and sectors in which they worked. It was also not appropriate to disaggregate responses according to organisation, because interviewees had been instructed to answer from personal experience.

\section{Results}

\subsection{Questionnaire Part 1: Characterising Respondents}

An analysis of the respondents to the questionnaire shows the wide range of people interviewed, from different organisations, sectors, and expertise. A total of 109 questionnaires were completed. The average number of years that respondents had worked professionally on river-related issues was 16 years, while the average time in the current position was 9 years. Nineteen of the persons interviewed were very senior in their organisations (i.e., Chief Executive Officers (CEOs), country directors, professors, Director Generals (DGs) etc.). This is indicative of the experience and familiarity of the respondents with the rivers being considered.

These results are shown graphically in Figures 2-4. Out of 109 respondents, 66 were nationals of the six countries, with the greatest number coming from Viet Nam, which was the result of the questionnaire being applied by a group of protected area managers from the Mekong Delta in a training course on ecosystem service valuation. The smallest number of representatives originated from China. The other respondents were internationals from various countries who had been working on rivers in the region. Many of the respondents (both nationals and internationals) had worked in several of the countries, so that out of the 109 respondents, 85 had worked in Viet Nam, 60 in Cambodia and Laos, 51 in Thailand, 41 in Myanmar, and 21 in China.

The proportion of respondents with experience of the major river systems, showed that $46 \%$ of respondents had worked on the Lancing/Mekong, $16 \%$ and $10 \%$ working on the Ayeyarwady and Chindwin river systems, and $12 \%$ on the $\mathrm{Nu}$ /Salween/Thanlwin. Twelve percent had experience of Chao Phraya and 7\% had experience on the Red River. Many respondents indicated that they had worked in several different types of organisation during the course of their careers, so that there was a fairly even spread between government agencies $(15 \%)$, intergovernmental/regional organisations $(11 \%)$, river basin organisations $(12 \%)$, research organisations (20\%), academic institutions (9\%), INGOs $(11 \%)$ and private sector/consultants $(16 \%)$, with a smaller representation of NGO/CSOs and development banks/partners ( $3 \%$ each).

An analysis of the sectors and jobs that respondents had worked in showed that a very high proportion worked in the domestic water supply and protected area management sector ( $>60$ respondents), possibly weighted by the group from Viet Nam. This was then followed by those who had worked in the hydropower sector $(>50)$, capture fisheries, irrigation, and agriculture, all of which had more than 40 respondents. Other sectors such as forestry $(>20)$, aquaculture, navigation, wastewater treatment, and industrial water supply had between 10-20 respondents, and tourism and recreation had 10 respondents. 
a)

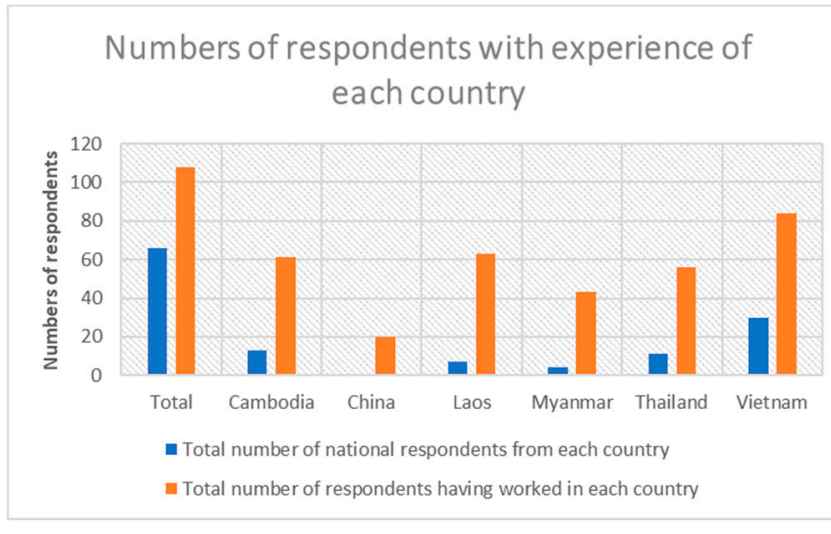

b)

Proportion of respondents with experience of SE Asian rivers

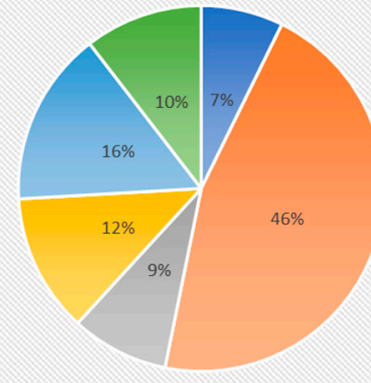

- Red river

- Lancang Mekong

- Chao Phraya

- Salween

- Ayeyarwady

- Chindwin

Figure 2. (a) Numbers of respondents with experience of each country (b) Proportion of respondents with experience of selected SE Asian rivers.

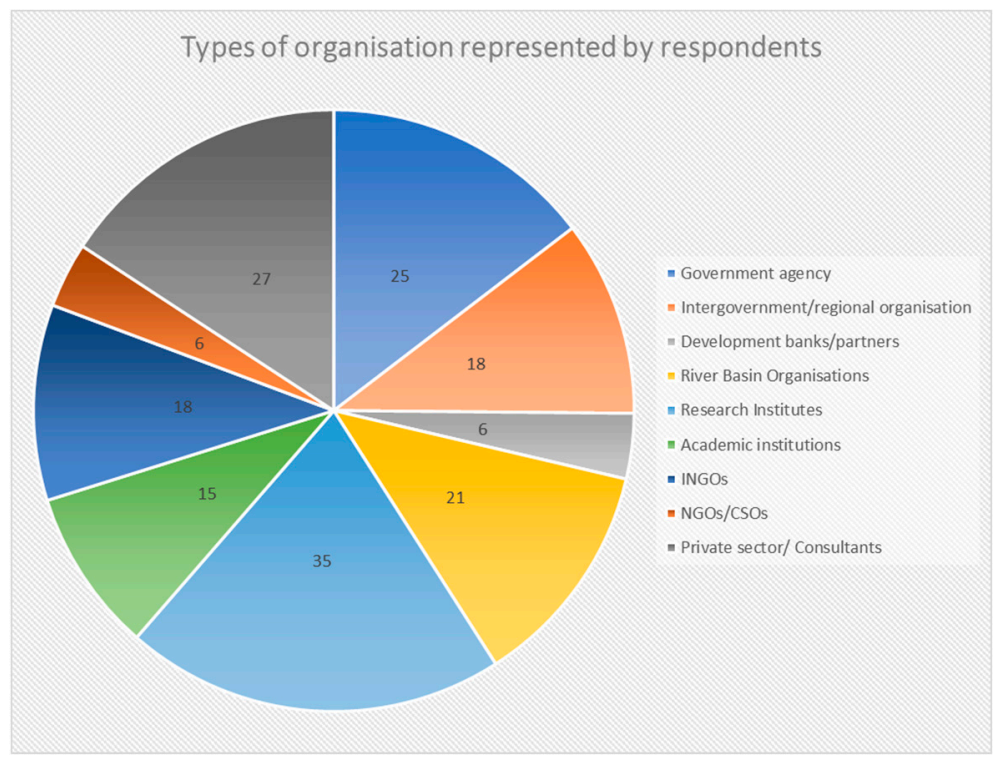

Figure 3. Types of organisations represented by respondents.

a)

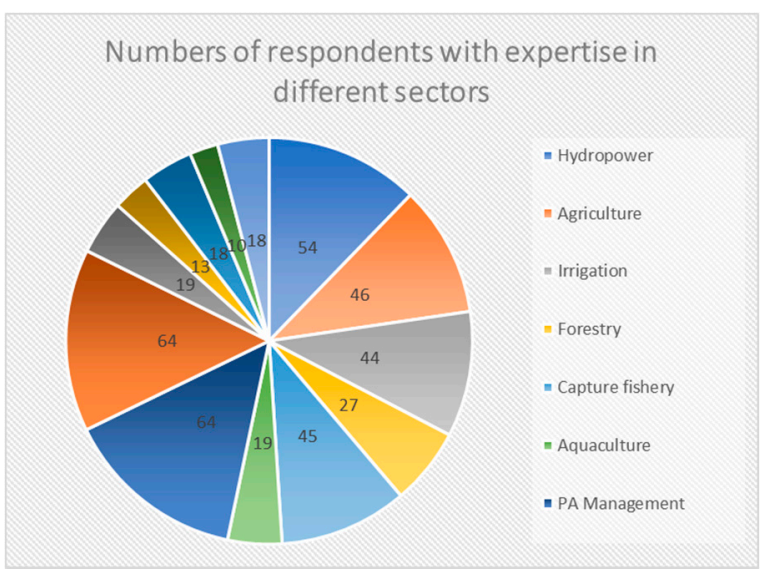

b)

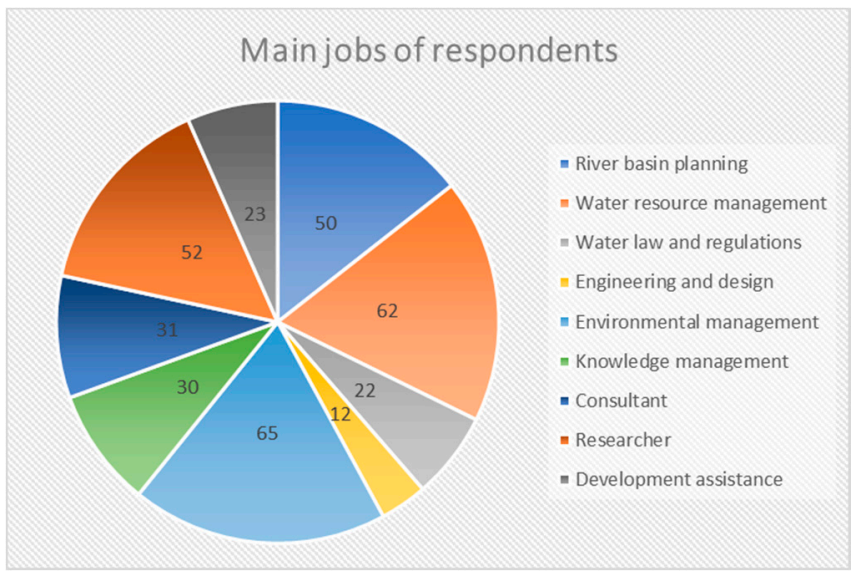

Figure 4. (a) Numbers of respondents with expertise in different sectors (b) Main jobs of respondents.

The main jobs of respondents were in environmental management, water resource management, and river basin planning, and as researchers with more than 50 respondents. 
There were about 30 each for consultants and knowledge management, and over 20 for water law and regulations and development assistance. There were over 10 with engineering and design as their main jobs. Because respondents had had experience in different sectors and organisations, it was not possible to differentiate their responses to the ecosystem service questions, nor was it possible to distinguish their ecosystem service priorities for the different rivers. The results of this survey provides a generalised view of the river ecosystem service priorities across the region and sectors, rather than being specific for different rivers, countries, or sectors.

\subsection{Questionnaire Part 2: Need and Uses for a River Ecological Importance Framework}

The respondents were first asked, "Has the absence of a system or framework for measuring and mapping ecological importance of rivers ever restricted your work?". Out of the 109 respondents, $62 \%$ indicated that the absence of such a system had indeed restricted their work or it would have been helpful to have had such a system, while $11 \%$ did not think their work had been restricted; $27 \%$ did not know or did not answer, probably because they were not entirely sure what such a system would consist of.

Interviewees were then asked to rank nine suggested uses for such a framework. The ranked uses and additional comments are shown in Figure 5. All the suggested uses scored relatively highly, i.e., with weighted scores between 2 and 3 (i.e., between Medium and High on aggregate).

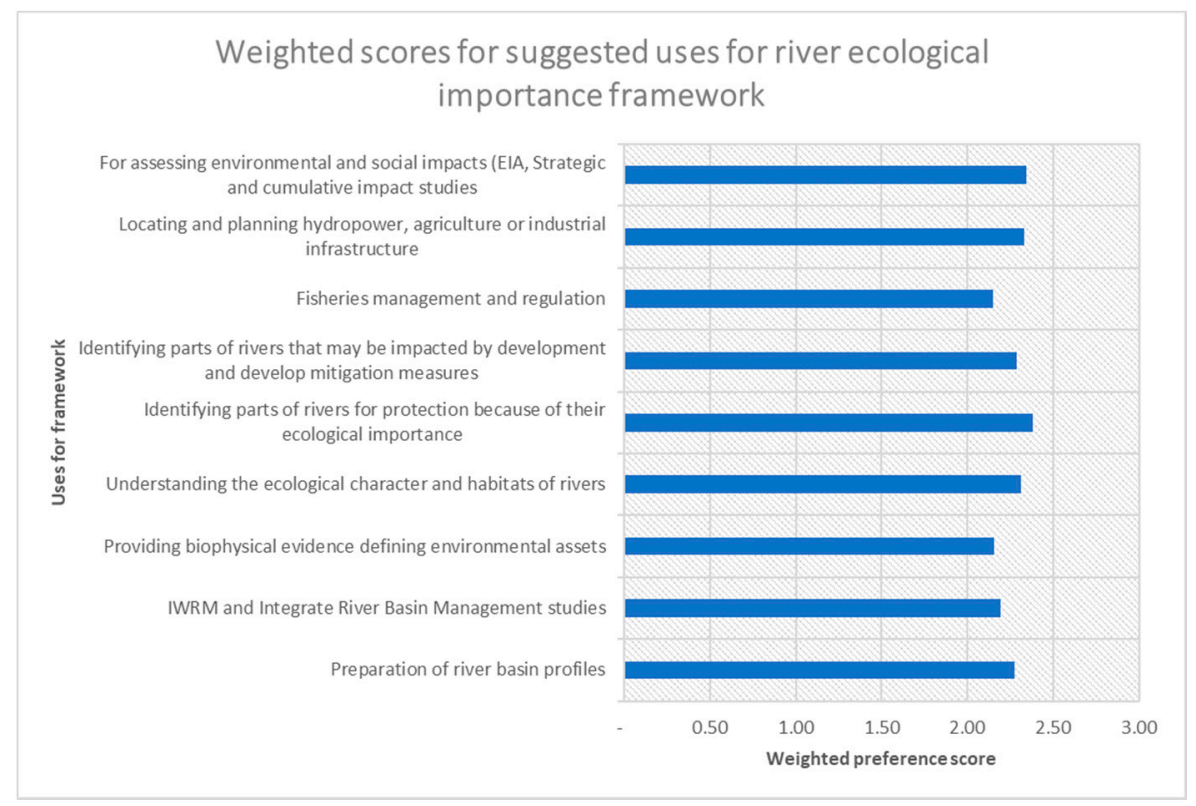

Figure 5. Weighted scores for suggested uses of river ecological importance framework.

Several interviewees commented that projects would have been easier with such a framework in place, for example, "how good it would have been to have such a scheme". They considered that the lack of clear information and a standardised system might delay and restrict survey and planning work, and it would be helpful to have such a system. The IWRM specialist of a river basin organisation noted that the "absence of a system did not really restrict the work, but the proposed framework would certainly have been supportive of identifying significant tributaries".

Comments from respondents indicated support for each of the suggested uses. A senior manager from Mekong River Commission said that “ . . before 2010 there was nothing like this and such a system would have been helpful. Now MRC has been identifying environmental assets of regional importance and developing strategies to protect these assets." A consultant involved with mapping protection areas for the MRC mentioned that 
“... a study on the Srepok river for MRC was designed to come up with such system, but this has never been applied at basin scale".

The use of a framework for assessing environmental and social impacts was confirmed by another environmental consultant, saying " ... in all our Strategic Environmental Assessment work there was little initial recognition of biodiversity and we started from scratch to identify and map ecological importance, using Protected Areas, and Key Biodiversity Areas". The country director of a conservation NGO in Cambodia noted that "When such a system does not exist, we do not have a real baseline to assess impacts and transformation of rivers".

The use of the framework for locating and planning hydropower, agriculture or industrial infrastructure was confirmed by a sustainable hydropower planner saying " ... it would be helpful for the developer during site selection and design." And a professor from an Australian university doing research in the Mekong mentioned that "... when assessing how dam projects will reduce fish production, it would be helpful to use the framework to triage impacted river reaches".

For river basin planning, the environmental director of an INGO noted that without such a system it was "hard to decide on project areas for application of green infrastructure in one of the Mekong tributaries and where to select implementation sites". A research scientist in land and water development planning noted that "in the Ayeyarwady Master Planning process, sub-basin analysis was helped by the development of a system to help in understanding of flow ecology relationships."

Senior programme officers in a regional INGO noted that " ... when we have proposals to select target areas for fisheries conservation, we don't have a sound and consistent system based on scientific information. To protect the fish integrity, we have to know the suitable locations to work in. For example, the $3 S$ rivers are important for spawning in the Mekong system, but we cannot highlight areas on the map". The director of a national fisheries research institute confirmed that "... more ideas and knowledge about features and characteristics of habitat makes planning more effective," and a system could be used for "quantifying the level of wetland that has been obstructed, and identifying opportunities for fish passage".

The lack of information about many of these rivers was noted and the development of a framework would help to define the core values, for example, in the Salween there are significant gaps. The head of research in the Faculty of Economics at a national university in the region noted that "there are very few studies or documentaries to evaluate the values of river reaches, so it is difficult to determine values within a concession". The ex-CEO of a river basin organisation mentioned that "if such a system had existed it would give a better science-based foundation for decision makers, noting that river-basin organisations can be very political".

If all those that responded "Don't Know" are excluded and the preferences of those that scored the different uses are analysed by aggregating the responses by both respondent job types and all the sectors that they had worked in, we were able to rank the uses suggested. All nine uses scored very highly between 2.6 and 2.9, but the top four uses were clear, as shown in Table 4-identifying rivers for protection, understanding the ecological character and habitats of rivers, and assessing environmental and social impacts on rivers, followed by locating and planning infrastructure developments (See Appendix C). 
Table 4. Ranking of uses by respondents aggregated by job type and sector.

\begin{tabular}{lcc}
\hline \multicolumn{1}{c}{ Use of Ecological Importance Framework } & Ranking by Job Type & Ranking by Sector \\
\hline $\begin{array}{l}\text { Identifying parts of rivers for protection } \\
\text { because of their ecological importance }\end{array}$ & 1 & 2 \\
\hline $\begin{array}{l}\text { Understanding the ecological character and } \\
\text { habitats of rivers }\end{array}$ & 2 & 3 \\
\hline $\begin{array}{l}\text { Assessing environmental and social impacts } \\
\text { (EIA, strategic and cumulative impact studies }\end{array}$ & 3 & 1 \\
\hline $\begin{array}{l}\text { Locating and planning hydropower, } \\
\text { agriculture, or industrial infrastructure }\end{array}$ & 4 & 4 \\
\hline $\begin{array}{l}\text { Providing biophysical evidence defining } \\
\text { environmental assets }\end{array}$ & 5 & 5 \\
\hline $\begin{array}{l}\text { Identifying parts of rivers that may be } \\
\text { impacted by development and develop } \\
\text { mitigation measures }\end{array}$ & 6 & 6 \\
\hline Preparation of river basin profiles & 7 & 8 \\
\hline $\begin{array}{l}\text { IWRM and Integrate river basin } \\
\text { management studies }\end{array}$ & 9 & 9 \\
\hline Fisheries management and regulation & 9 & 5 \\
\hline
\end{tabular}

\subsection{Questionnaire Part 3: Preferred River Ecosystem Services}

In this section, the average preference scores and ranking of the different ecosystem services have been analysed and plotted on radar diagrams (Figures 5-8). The highest scoring ecosystem services are circled.

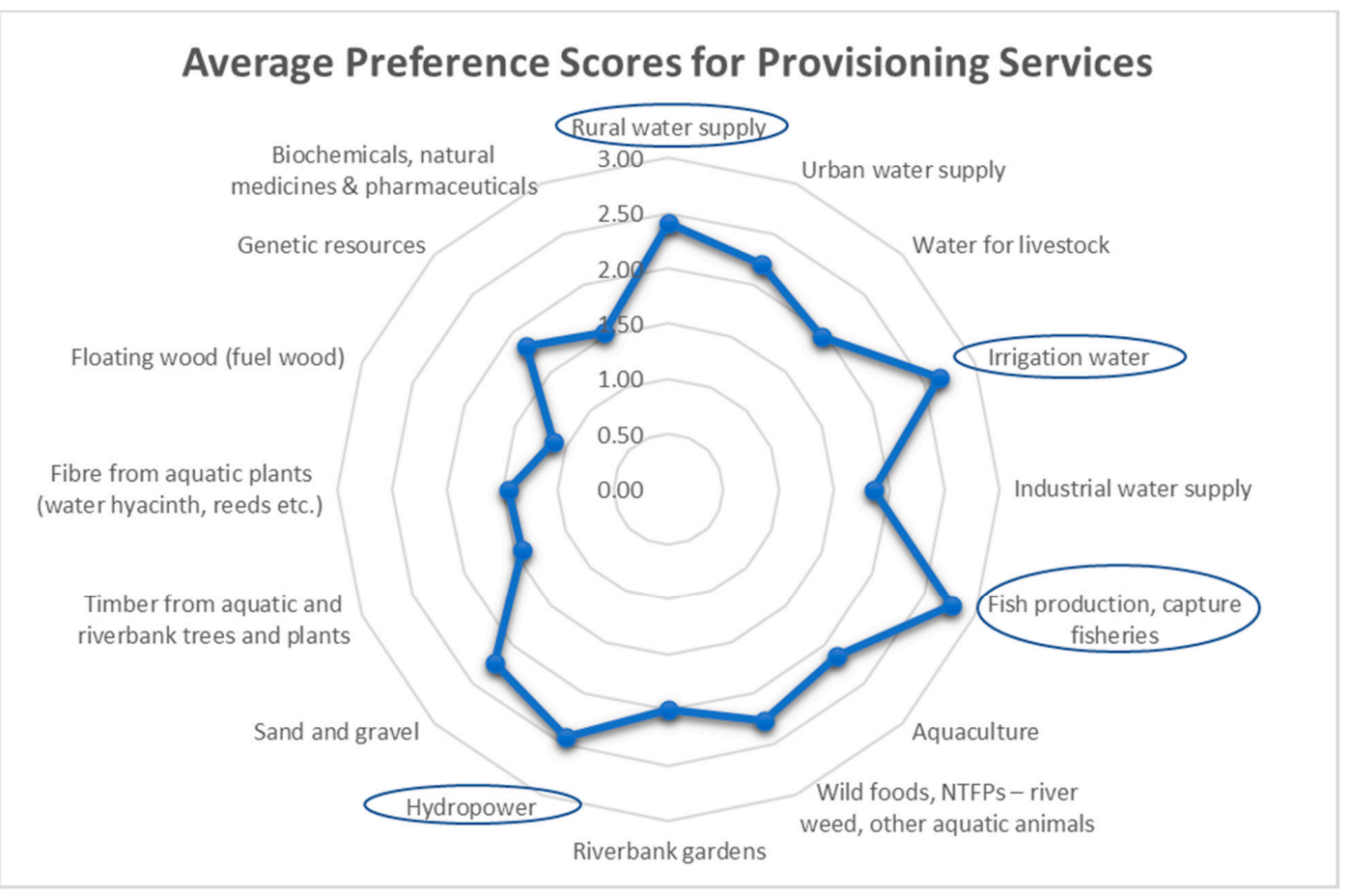

Figure 6. Average preference scores for provisioning services of South East Asian rivers (highest scoring services circled).

\subsubsection{Preference Scores for Provisioning Services}

Provisioning ecosystem services are the products that people obtain from the ecosystems. In the context of South-East Asian rivers, respondents identified the three highest 
scoring provisioning services as fish production and capture fisheries, water for irrigation and hydropower, followed by rural water supply, urban water supply, wild foods and NTFPs, and sand and gravel. The average preference scores for provisioning services of rivers are shown in Figure 6. Conversely, genetic resources, biochemicals and natural medicines, and floating wood were considered to be less important.

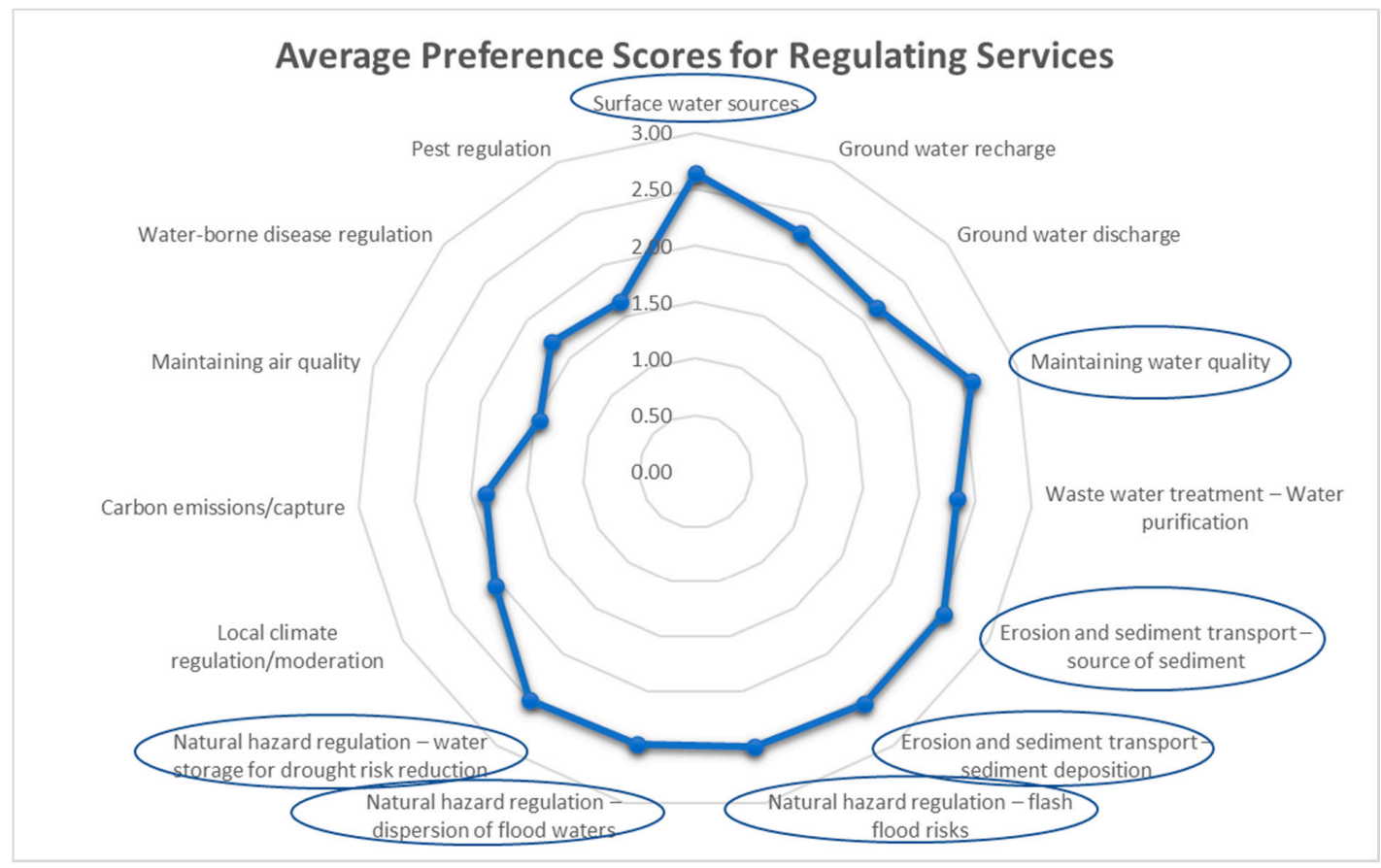

Figure 7. Average preference scores for regulating services of South East Asian rivers (highest scoring services circled).

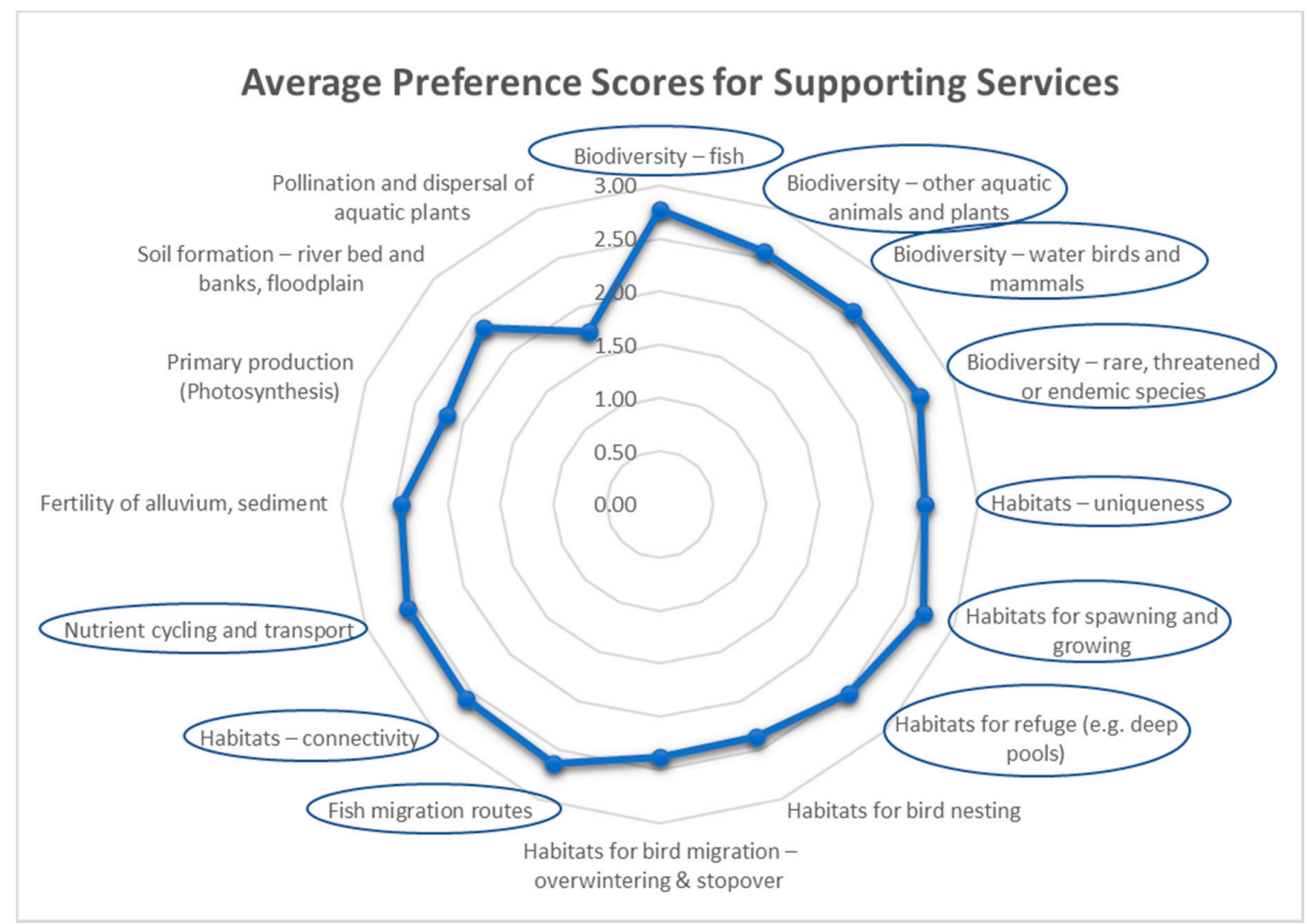

Figure 8. Average preference scores for supporting services of South East Asian rivers (highest scoring services circled). 
Discussions with respondents indicated that an assessment of importance of provisioning services often depended upon who was benefiting from the service, and the level of assessment-global, national or local. This is also reflected in the fact that rivers or tributaries which have differing geographic, biological, and economic characteristics, are likely to have more or less important provisioning services; this in itself provides a reason for preparing such a mapping framework. An example of these differences is the importance of river weed as a food product in the upper Mekong in Laos and Thailand, compared to the Lancang tributaries in Yunnan and lower reaches of the Mekong.

\subsubsection{Preference Scores for Regulating Services}

Regulating services of rivers are those that regulate and maintain ecosystem processes, and facilitate ecosystem functioning and productivity. The preference scores (Figure 7) prioritise surface water flows, maintaining water quality, and sediment source and deposition. These were followed by three forms of natural hazard regulation, flash floods, flood water dispersion, and storage of water for drought risk reduction. All of these had preference scores above 2.5. Slightly less important regulating services included ground water recharge and discharge, while the roles of rivers in local climate moderation, pest and water borne disease regulation and maintaining air quality were considered of lower importance. As with provisioning services, discussions with interviewees indicated that river reaches and sub-basins will be performing different regulating services depending upon their character and geomorphology; for example, the sub-basins that are important sources of sediment will not be the same as those alluvial reaches where sediment is deposited, similarly for groundwater recharge and discharge.

\subsubsection{Preference Scores for Supporting Services}

Supporting ecosystem services are those that are necessary for the production and maintenance of ecosystem structure and function. The provision of living spaces for plants or animals and maintaining a diversity of plants and animals are 'supporting services' and the basis of all ecosystems and their services. Interviewee preference scores (Figure 8) indicated that most of the riverine supporting services scored very highly, especially those grouped under biodiversity and habitats all scoring above 2.5 with "fish diversity" and "habitats for spawning and growing" prioritised in these two groups. Fish migration routes and connectivity of the rivers, nutrient cycling and transport and the fertility of alluvium and sediment all scored highly above 2.5 . The only services that scored substantially lower than 2.5 were primary production and soil formation while the pollination and dispersal of aquatic plants scored below 2.00 .

\subsubsection{Preference Scores for Cultural Services}

Cultural ecosystem services are the non-material benefits that people obtain from riverine ecosystems through spiritual and religious values, aesthetic values, recreation, ecotourism, education and research. Locational values, for example, proximity of communities to the river and confluences and protected areas and political boundaries reflect cultural choices, and transport and navigation are included under cultural services. The prioritisation of the cultural services (Figure 9) showed that protected areas and spiritual and religious values of the rivers ranked the highest above 2.5 , followed by ecotourism and aesthetic values and transport and navigation. Cultural values such as boat racing and festivals, locational value, recreation, and education and research all scored above 2.0 with rivers serving as political and administrative boundaries scoring just under 2.0.

\subsection{Questionnaire Part 4: Preference Scores for Threats and Pressures}

The preference scores for threats and pressures upon the river ecosystems are derived from human activities and developments on the rivers in particular locations. In the absence of comprehensive river health monitoring, the intensity of these activities or disturbance by developments may be taken to reflect the condition of the river. The threat to a healthy river 
ecosystem may be over-use or abuse of its river ecosystem services. The preference scores for threats and pressures are shown in Figure 10. The highest priority threats and pressures included fishing pressures, changes in seasonal flows and water storage reservoirs for hydropower, irrigation and water supply, scoring above 2.5, and closely followed by dams and barrages, landuse changes in the catchment from deforestation and agricultural conversion. Pollution pressures and sand and gravel mining all scored between 2.0 and 2.5, especially agricultural and urban run-off. The lowest scoring pressures, just under 2.0, were navigational pressures causing oil pollution and bank erosion, and alluvial gold mining.

\section{Average Preference Scores for Cultural Services}

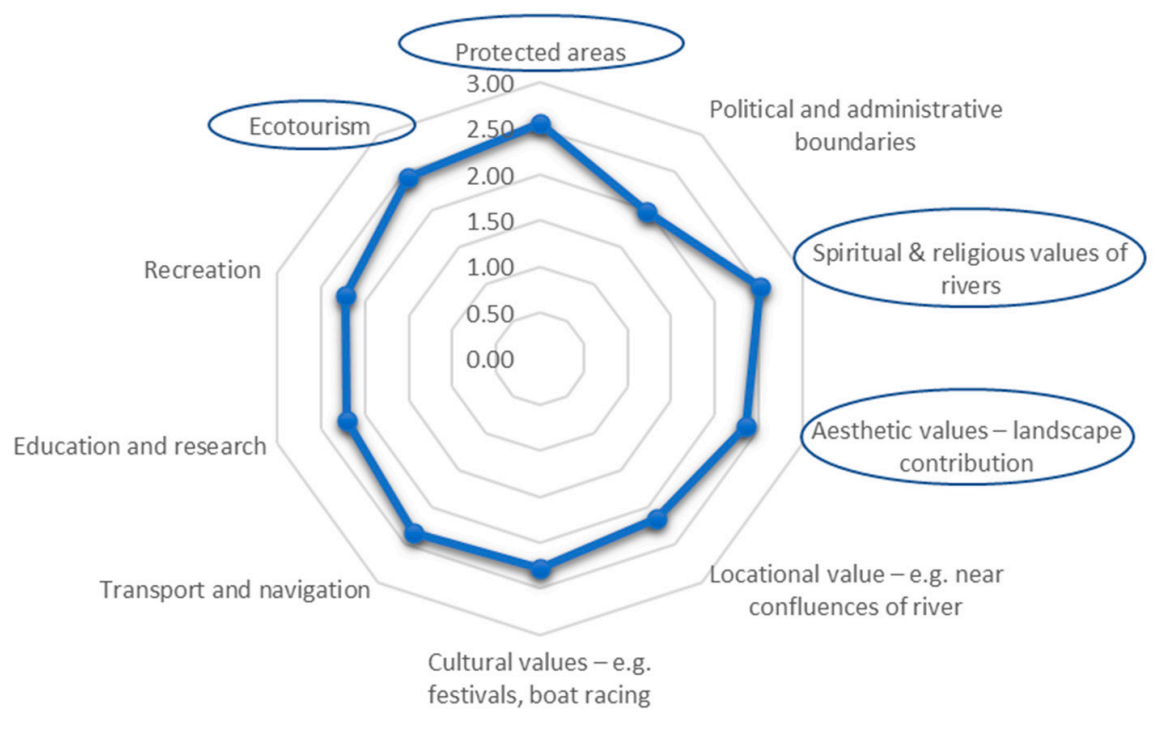

Figure 9. Average preference scores for cultural services of South East Asian rivers (highest scoring services circled).

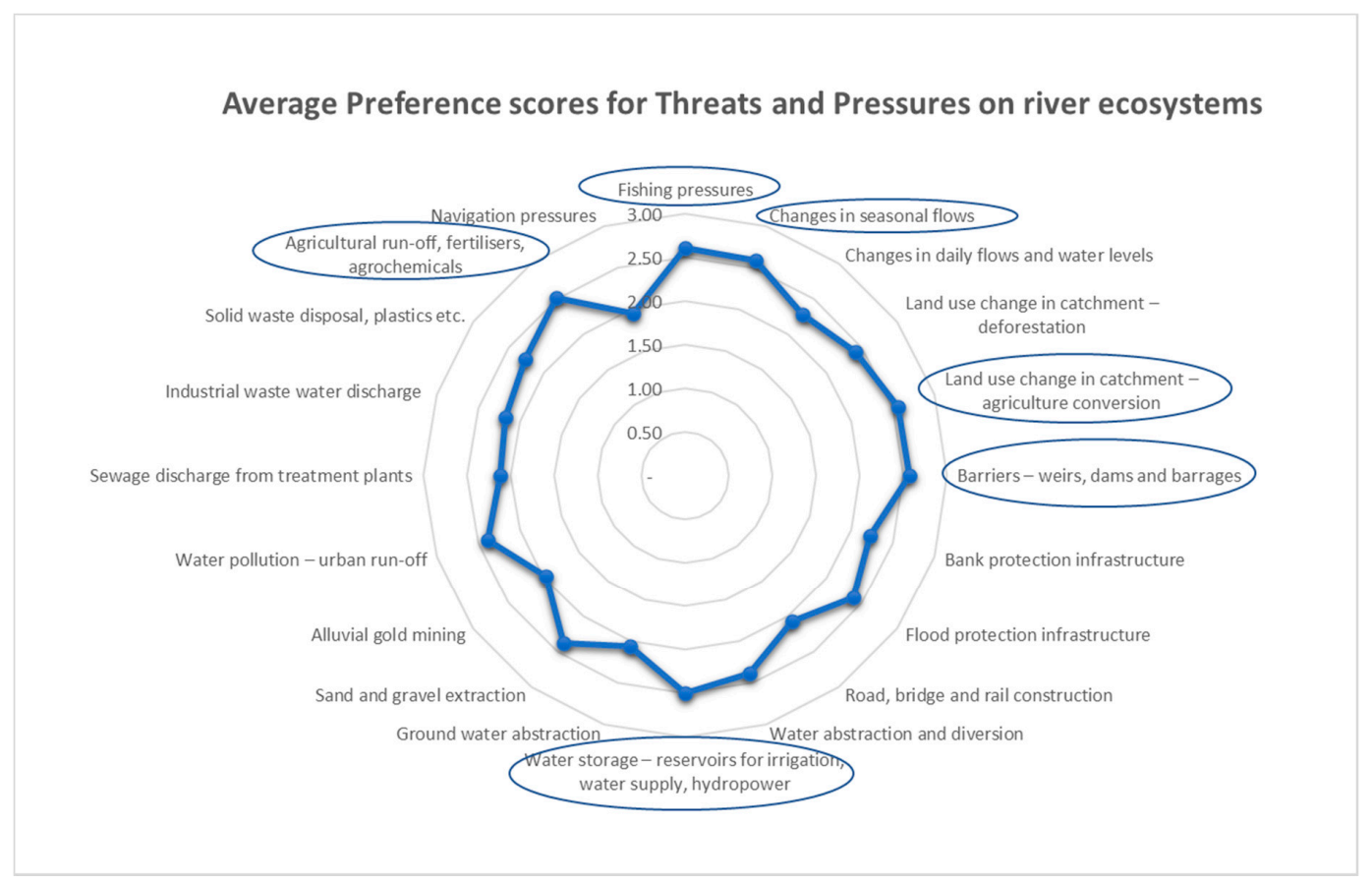

Figure 10. Average preference scores for threats and pressures on South East Asian rivers (highest scoring threats circled). 


\section{Discussion}

\subsection{Need and Uses of an Ecological Importance Framework}

The most significant finding is that there is strong support amongst the interviewees for adopting a greater focus on the concept of 'river ecosystem services' in general and agreement by the majority of the respondents for relatively similar prioritisation for the many different ecosystem services explored. The framework of ecological importance would present a different view of the river networks complementing the focus of frameworks used in other parts of the world, which have focused on the ecological character, water quality, and river health, rather than on ecosystem services $[2,13,14,16]$. As Schmutz and Sendzimir have indicated, other frameworks are focused on assessing degradation, using biotic indices, ecosystem health, and resilience [12], while the proposed framework of ecological importance would assess why river reaches and their sub-basins are valuable.

Many of the indices that have been used in other parts of the world depend upon detailed survey and monitoring data, which are not as comprehensive in the rivers of South East Asia, although the Mekong River Commission has been monitoring hydrological and sediment transport, water quality, and river health for the mainstream Mekong more consistently over the past decade. [11,23,24]. The first Ayeyarwady State of the Basin report published in 2017 tried to pull together the rather dispersed data on the character, uses, and condition of the river for the first time [26]. In 2007, the Asian Development Bank Core Environment Programme produced a series of Environmental Performance Assessments for the countries of the Greater Mekong sub-region, which rated inland water pollution and water resources as the two highest priority environmental concerns [33-35]. Whilst not discounting the value of indicators of river flow and quality which can be monitored using technology, it is also clear that other measures of ecosystem services which might be assessed through proxies such as geomorphology, land use or from earth observation, can enrich the scope and diversity of indicators.

The questionnaire was designed to assess the opinions of individual potential users rather than the views of organisations. Since most of the potential users had different jobs and worked in different sectors, it was not possible to distinguish the preferences that would apply to specific sectors. Over $60 \%$ of those interviewed confirmed that such a system would indeed facilitate their work. While a framework of ecological importance was recognised as being helpful for all the suggested uses, the highest ranked uses for the framework were (1) identifying parts of rivers for protection because of their ecological importance, (2) understanding the ecological character and habitats of rivers, and (3) assessing environmental and social impacts, followed closely by (4) locating and planning hydropower, agriculture, or industrial infrastructure. The results provide sufficient justification for the development and operationalising of such a framework of ecological importance for the rivers of South East Asia.

\subsection{Priority Ecosystem Services}

The main questions in the survey have allowed us to identify which ecosystem services potential users consider to be important in the rivers of South East Asia and hence should be included in the framework of ecological importance. The resulting preference scores for each ecosystem service are taken as indications of priority for inclusion.

In prioritising the different ecosystem services, the higher preference scores for provisioning services such as food, water supply, and hydropower compared to fuel, fibre, and genetic resources coincides with the focus of recent "nexus" studies examining development trade-offs on water, food, and energy in different river basins [36,37].

Amongst regulating services, surface water flows, water quality services, regulation of sediment transport, and natural hazard regulation all score very highly compared to the services that are less easy to visualise such as local climate moderation, carbon emissions from rivers, and regulation of pests and water borne diseases. These higher preference scores mirror the focus for hydrological and sediment transport models that form part of basin master plans [21,38], and flood and drought modelling and predictions. 
Water quality is the main component of river health monitoring, both chemical and bioassessments [23,24].

The supporting services prioritised the different aspects of biodiversity and habitats, and other ecological processes necessary for the healthy functioning of rivers, such as nutrient cycling and transport, and the fertility of sediments. All the biodiversity and habitat aspects had very high preference scores (over 2.5), especially for fish and habitats for spawning and growing. Rare, threatened, and endangered species and habitat uniqueness were ranked highly, as were connectivity and fish migration. Lower scoring supporting services included primary production, soil formation for maintaining riverbed, banks and floodplains, and pollination and dispersal of aquatic plants. It is clear from these highranking responses that these aspects of biodiversity and habitat should be featured in a system of river ecological importance. These features lie at the heart of environmental flow assessments, where the influence of changing flow regimes upon the geomorphology, habitats, and biotic communities is estimated to establish the range of acceptable change [39]. The BioRA (Biological Resources Assessment) of the Mekong River Commission's Council Study has applied the DRIFT (Downstream Response to Imposed Flow Transformations) methodology for assessing projected flow scenarios [40,41].

Cultural ecosystem services were generally rated slightly less highly than supporting services, although protected areas, which was classed as a cultural service because it is a landuse designation and value, was ranked highest, followed by spiritual and religious values and aesthetic landscape values with preference scores around 2.5. These cultural services are often difficult to define spatially because they are much less tangible and quantifiable than the biophysical services [42]. Ecotourism values of rivers had a high preference score because they have an obvious economic potential. In other parts of the world, ecotourism values have been mapped using attributes such as singular natural resources, scenic beauty, accessibility, tourism attraction capacity, and tourism use aptitude [43]. All the other cultural services were more moderately ranked with preference scores between 2 and 2.5. Rivers used as political and administrative boundaries scored the lowest preference score, though the natural boundaries provided by rivers are clearly a very significant cultural and political service; a recent global geospatial database has mapped rivers as national and sub-national borders [44].

It was not possible with this survey to identify which ecosystem services were considered more or less important for the different rivers in the region because respondents were answering the questions in the region as a whole, rather than for a specific basin. Many respondents had experience of several rivers in the region. Nevertheless, follow-up discussions during the interviews illustrated that every river, tributary, and sub-basin will have different levels of importance for each ecosystem service. For example, the provisioning of river weed from the rivers of northern Laos is a very specific resource and tradition [45], which is not found elsewhere, for example, in the rivers in Yunnan or lower down the Mekong in Cambodia. The spiritual value of the $\mathrm{Nu}$ /Salween river is unique because of the different ethnic groups, which depend upon this river compared to other rivers in this region $[46,47]$. Habitat and biodiversity values depend upon the geomorphology, flows, and ecoregional character, so that endemic species of fish and other aquatic animals are more likely to be found in the more remote upland rivers and headwaters [48], while the floodplains are likely to be more productive and allowing dispersal of flood waters. The implication is that a framework of ecological importance should cover a wide range of ecosystem services to capture this diversity between different rivers, and even in different stretches of the same river.

\subsection{Main Threats and Pressures}

In the absence of specific water quality or river health monitoring data, the presence of infrastructure, such as dams and reservoirs for irrigation and hydropower, urban run-off and wastes from mining, and other industries causing pollution, can all be indicative of threats to river ecosystem health. While most of the threats and pressures considered 
in the survey scored between medium and high, the highest scoring threats related to changes in seasonal flows from water abstraction and diversion, and barriers from dams and weirs affecting connectivity, followed by the factors affecting water quality. Reservoirs involve loss or change of habitat, converting the free-flowing rivers into lacustrine habitats. Generally, these are point sources of flow change, habitat loss, and pollution, which are generally well-defined spatially. The challenge will lie in determining the area of influence upstream and downstream of these different points on the river network. Such is often the task of impact assessment, especially of large water resource infrastructure, for example in strategic environmental assessments of hydropower and in river basin master planning [49-51].

However, some threats are more dispersed such as those affecting water quality from agricultural run-off, and land use change and deforestation in the catchment tending to increase soil erosion and sediment transport. These non-point sources would have to be considered on a sub-basin basis reflecting the degree of pressure caused by land uses in each sub-basin, and the cumulative pressures from each sub-basin with flow downstream.

Often the threats and pressures upon a river system reflect over-use or abuse of an ecosystem service. The pressure from over-fishing or use of illegal fishing methods, such as electrofishing or dynamite is the prime example of this. A fisheries specialist interviewed noted that often the places most suitable for fish production were the very places where pressures from over-fishing were the highest and that these were directly related to the numbers of fishermen.

The definition and mapping of threats and pressures can be indicative of the integrity and health of the river ecosystems and will depend upon location and intensity of human activities. In many cases, these will reflect the rural and urban populations using the ecosystem services provided by the river.

\subsection{Next Steps to Develop an Ecological Importance Framework}

The inspiration for developing such a framework of ecological importance for the rivers of South East Asia has come from the development of the GloRiC (Global River Classification) system of river reach classification [52]. This framework uses the HydroSHEDS database [53] to provide the river reach network and the associated HydroBASINS, which delineate the river sub-basins [54] (https://www.hydrosheds.org/overview, (accessed on 4 June 2021). World Wildlife Fund Inc. Washington, DC, USA \& McGill University, Montreal, QC, Canada). An earlier subset of the GloRiC framework was developed for the Greater Mekong region (GMR) for WWF Greater Mekong [55]. This river reach classification creates 70 sub-classes of river reach with the GMR based upon hydrologic, physio-climatic, and geomorphological classes using river size and flow, elevation and slope, eco-region, karst and river geomorphological criteria. This framework was used in earlier river ecological sensitivity mapping carried out for studies for Nam Ou river basin profile in Northern Laos and the Strategic Environmental Assessment of Hydropower in Myanmar for the International Finance Corporation (IFC) $[50,56]$. The GloRiC framework has also been used to map river connectivity and free-flowing rivers of the world [4]. GloRiC will provide the river networks for the framework of ecological importance to capture the diversity and distribution of ecosystem services in different rivers, adding the biological and human use criteria to this existing classification.

A starting point for ecosystem classification is WWF's Terrestrial Ecoregions of the World, which defines biogeographic regions as "relatively large units of land or water containing a distinct assemblage of natural communities sharing a large majority of species, dynamics, and environmental conditions" [57]. However, the 41 different ecoregions within the Greater Mekong region are largely terrestrial although wetlands such as mangroves and swamp forests are included. These are classifications of the original ecosystem types, which only reflect the rarity or threat when the loss or change in extent is compared over time. The companion Freshwater Ecoregions of the World (FEOW) [58] fills this gap to some extent, but in the Greater Mekong region, the 17 FEOWs are largely based upon whole 
river basins or large sub-basins with five different, rather unspecific, freshwater habitats. Even the Ramsar Convention's classification of wetlands includes only four categories of riverine wetlands [59]. The recent IUCN Redlist assessment of threatened ecosystems of Myanmar [60], which maps both extent and condition, focuses on terrestrial ecosystems, except for mangroves and swamp forests. However, it does not distinguish the riverine ecosystems running through these landscapes in Myanmar.

The challenge in developing this framework of ecological importance lies in the identification of appropriate indicators for the different ecosystem services together with methods of measurement and the availability of relevant data. Discussions with interviewees have suggested some indicators and methods of measurement of these ecosystem services, which may depend upon (a) global or regional datasets, (b) interpretation of remote sensing imagery, and (c) nationally or locally available information. These insights have been complemented by reviewing methods for measuring ecosystem service indicators used by the Ecosystem Services and Resilience Framework [31] and the Hydrological EcoSystem Services (HESS) developed by the CGIAR (formerly the Consultative Group on International Agricultural Research) focusing on those ecosystem services that explicitly describe the services derived from water resources, including consumptive uses [32]. We have also considered the Mekong River Commission's Strategic Indicators used to provide a basin-wide view of current and past conditions in the Lower Mekong Basin [29] and those included in the recent Decision Support System for the Ayeyarwady River Basin Master Plan [51].

There has been little emphasis on the comprehensive mapping of river ecosystem services generally within the region, and studies have considered individual ecosystem services rather than the full set of services. Some ecosystem services have received a great deal of attention on a sectoral basis, for example the Mekong River Commission's flood and drought management and International Water Management Institute's (IWMI) flood mapping in South East Asia (http:/ / waterdata.iwmi.org/Applications/Southeast_ Asia_Flood_Mapping/ (accessed on 16 April 2021)). Mapping of the river potential for hydropower has been done in the various river basin and hydropower master plans and impact assessment studies [50,51,61,62]. Fish species distribution, migration, and production has been the subject of a wide range of studies by the MRC and WorldFish and these are usually quite specific to some parts of the river basins [63-68]. The ranges of some aquatic threatened and endemic species have been mapped as part of the IUCN Red List process and these have been described for the Indo-Burma region [48].

There have been some initiatives in assessing and valuing ecosystem services in specific areas within the region, but these have not been upscaled or mapped across river basins. For example, a state and impact assessment framework was developed and applied to evaluate river health and the impacts of hydropower projects on the Lancang river in Yunnan [69], and Conservation International have applied their Freshwater Health Index in the $3 S$ (Sekong, Sesan, Sre Pok) tributaries of the Mekong [70]. The Freshwater Health Index is built up using three groups of indicators covering Ecosystem Vitality (i.e., condition and integrity), Ecosystem Services (such as water supply, biomass for consumption, sediment and flood regulation and conservation and cultural heritage sites), and Governance \& Stakeholders (regulatory capacity) [71].

A preliminary scoping of the feasibility of measuring indicators of these ecosystem services is now being conducted. The feasibility will be estimated by identifying the potential indicator to be measured and then assessing it according to four questions (a) Has the indicator been clearly defined? (b) Has the method of measurement been described? (c) Is the data readily available? (d) Does the data cover the region as whole or only part of the river systems?

The feasibility of measurement scores will be compared with the preference scores for each ecosystem service in the matrix. This allows grouping of the ecosystem services into four quadrats-High Preference/High Feasibility, High Preference/Low Feasibility, Low Preference/High Feasibility, Low Preference/Low Feasibility. Initial findings suggest 
that about one-third of the high preference scoring ecosystem services are relatively easy and the data is readily accessible. For example, the mapping of river reaches flowing through protected areas, or along political boundaries will be simple; global datasets, such as the World Database on Protected Areas (WDPA), Key Biodiversity Areas and Global Subnational River-Borders (GSRB) already exist [44]. Other indicators can be derived from population density or census data, for example, water supply calculated from populations in each sub-basin, or pressures due to urban run-off. Another third of the ecosystem services are likely to require further development of indicators and measurement methods but will be important to include because of their high preference scoring. These are expected to include the river reaches with high habitat and unique biodiversity status.

The remaining third of the highly preferred ecosystem services are more intractable and will require the identification and development of appropriate indicators, such as measures for groundwater recharge and discharge. The remaining ecosystem services have low preference scores and low feasibility of measurement, such as local climate moderation, pest and disease regulation services of rivers, and may be impossible to include in the development of the framework of ecological importance. As the indicators and methods of measurement and mapping are developed, consultations with expert groups selected from the stakeholders interviewed will ensure that they are relevant and appropriate.

\section{Conclusions}

We interviewed a wide and comprehensive cross-section of professionals and academics involved with river basin planning, water and natural resource management and use working on the rivers of South East Asia. The main findings were that the idea of such a framework, based on assessing the ecological importance of river reaches within the hydro-basins of the rivers in the Greater Mekong region, using a consistent set of indicators based on river ecosystem services, was strongly accepted by the majority of respondents as an important development by practitioners in all fields, across the six countries.

There was relatively strong consensus over a subset of the most preferred indicators that should be measured for rivers across all countries. The services prioritised most highly were (a) level of fish production; (b) fish diversity; (c) habitats for fish spawning and refuge; (d) presence or rare/endemic species; (e) potential to supply irrigation water and domestic water; (f) adequacy of surface water flow and maintenance of water quality; (g) connectivity with other river reaches; (h) protected status and uniqueness of habitat; (i) potential for hydropower; and (j) the less tangible cultural ecosystem services reflected by spiritual, religious and aesthetic values and potential for ecotourism. The selection of these indicators mirrors current interest in assessing the water-food-energy nexus, enabling river managers to simultaneously assess ecological as well economic value or importance, using a suitably diverse but internationally consistent set of indicators. River reaches scoring highly for both ecological and economic indicators enables one to identify areas where potential conflicts over use may occur.

An important finding was that many of the indicators that were most preferred for adoption by the majority of the respondents are relatively feasible, with some already partially operational in one or more countries, and hence could be extended to create a harmonised set of indicators across the Greater Mekong region. Others, such as identification of habitats for fish spawning, and improved measures of fish diversity, are not presently operational and are recognised as the next challenges for inter-basin river monitoring.

Although some of these indicators are contained in existing information systems, none are being implemented comprehensively across any geospatial river networks. However, the HydroSHED database and the GloRiC framework could be extended to incorporate this fuller set of indicators, even if not all can be measured currently in all six countries. Mapping using this framework across the river networks of South East Asia would fill a geospatial data gap of direct application in river basin planning, impact assessment, and identification of priority river basin reaches for protection and management. 
Author Contributions: Conceptualization, P.-J.M., M.M., and N.S.; methodology, P.-J.M., M.M., and N.S.; formal analysis, P.-J.M.; investigation, P.-J.M.; resources, P.-J.M.; data curation, P.-J.M.; writingoriginal draft preparation, P.-J.M.; writing—review and editing, P.-J.M., M.M., and N.S.; visualization, P.-J.M.; supervision, M.M. and N.S. All authors have read and agreed to the published version of the manuscript.

Funding: This research received no external funding.

Institutional Review Board Statement: This research was approved by the Institutional Ethics Committee of School of GeoSciences, University of Edinburgh (Number 2020-465, 1 March 2021).

Informed Consent Statement: Informed consent was obtained from all subjects involved in the study.

Data Availability Statement: The data presented in this study are available on request from the corresponding author. The data are not publicly available due to privacy of questionnaire respondents.

Acknowledgments: We would like to acknowledge the many persons and organisations who have taken part in interviews and other discussions about the research.

Conflicts of Interest: The authors declare no conflict of interest.

\section{Appendix A. Summarised List of Organisations Interviewed}

Table A1. Interviewees' Organisations.

\begin{tabular}{|c|c|c|c|}
\hline Organisation & Type & Countries Worked in & Interest \\
\hline $\begin{array}{c}\text { Mekong River } \\
\text { Commission (MRC) }\end{array}$ & River Basin organisation & $\begin{array}{l}\text { Laos, Cambodia, } \\
\text { Viet Nam, Thailand }\end{array}$ & $\begin{array}{l}\text { Basin planning, environment, } \\
\text { fisheries, hydropower, navigation }\end{array}$ \\
\hline $\begin{array}{l}\text { Asian Disaster Preparedness } \\
\text { Centre (ADPC) }\end{array}$ & International organisation & $\begin{array}{l}\text { Laos, Cambodia, Viet Nam, } \\
\text { Thailand, Myanmar, China }\end{array}$ & $\begin{array}{l}\text { Environment, disasters, rivers, } \\
\text { remote sensing }\end{array}$ \\
\hline Ministry of Environment & Government & Cambodia & Government protected areas \\
\hline Ministry of Environment & Government & Cambodia & $\begin{array}{l}\text { Freshwater Wetlands } \\
\text { Conservation }\end{array}$ \\
\hline Fisheries administration & Government & Cambodia & Fisheries research \\
\hline $\begin{array}{l}\text { Office of Nature and } \\
\text { Environment Protection }\end{array}$ & Government & Thailand & $\begin{array}{l}\text { Biodiversity, wetlands } \\
\text { management }\end{array}$ \\
\hline Dept. of Fisheries & Government & Thailand & Inland fisheries research \\
\hline $\begin{array}{l}\text { Hydro-Informatics Centre, } \\
\text { National Water } \\
\text { Resources Committee }\end{array}$ & Government & Myanmar & Government, river basin planning \\
\hline $\begin{array}{l}\text { Ministry of Natural Resources } \\
\text { and Environmental } \\
\text { Conservation (MONREC) }\end{array}$ & Government & Myanmar & $\begin{array}{l}\text { Environment regulation and } \\
\text { Impact assessment }\end{array}$ \\
\hline $\begin{array}{l}\text { Viet Nam National } \\
\text { Mekong Committee }\end{array}$ & Government & Viet Nam & $\begin{array}{l}\text { IWRM, planning, } \\
\text { river development }\end{array}$ \\
\hline Southern Institute of Ecology & Government, research & Viet Nam & Biodiversity, landscape ecology \\
\hline $\begin{array}{l}\text { Southern Institute of Water } \\
\text { Resources Research }\end{array}$ & Government, research & Viet Nam & Water resources \\
\hline $\begin{array}{l}\text { Research Institute for aquaculture } \\
\text { no } 2\end{array}$ & Government, research & Viet Nam & Inland fishery and aquatic ecology \\
\hline Tram Chim National Park & Government & Viet Nam & Protected areas \\
\hline Phu My Nature Reserve & Government & Viet Nam & Protected areas \\
\hline U Minh Thuong National Park & Government & Viet Nam & Protected areas \\
\hline Lang Sen National Park & Government & Viet Nam & Protected areas \\
\hline Australian Water Partnership & Development partner & Myanmar & Water planning, hydrology \\
\hline ACIAR & Research funding & $\begin{array}{l}\text { Laos, Cambodia, Viet Nam, } \\
\text { Thailand, Myanmar }\end{array}$ & Water and climate, river health \\
\hline CSIRO & Research & $\begin{array}{l}\text { Laos, Cambodia, } \\
\text { Viet Nam, Thailand }\end{array}$ & Land and water economic policy \\
\hline
\end{tabular}


Table A1. Cont.

\begin{tabular}{|c|c|c|c|}
\hline Organisation & Type & Countries Worked in & Interest \\
\hline $\begin{array}{l}\text { CGIAR-WLE, Mekong economics } \\
\text { Futures Research Institute }\end{array}$ & Research institute & $\begin{array}{l}\text { Laos, Cambodia, Viet Nam, } \\
\text { Thailand, Myanmar, China }\end{array}$ & Research programme \\
\hline $\begin{array}{l}\text { International Water Management } \\
\text { Institute (IWMI) }\end{array}$ & Research institute & $\begin{array}{l}\text { Laos, Cambodia, Viet Nam, } \\
\text { Thailand, Myanmar }\end{array}$ & $\begin{array}{l}\text { Global water management } \\
\text { research. Water futures, growth } \\
\text { and natural capital }\end{array}$ \\
\hline WorldFish & Research institute & Cambodia, Laos Myanmar & Global fisheries research \\
\hline Stockholm Environment Institute & Research Institute & $\begin{array}{l}\text { Laos, Cambodia, Viet Nam, } \\
\text { Thailand, Myanmar }\end{array}$ & $\begin{array}{l}\text { Environment and society, } \\
\text { Rivers research }\end{array}$ \\
\hline $\begin{array}{l}\text { Charles Sturt University Institute } \\
\text { for land water \& Society }\end{array}$ & Academic & $\begin{array}{c}\text { GMR } \\
\text { Laos, Myanmar }\end{array}$ & Wetland ecology, fisheries \\
\hline $\begin{array}{l}\text { The Australian } \\
\text { National University }\end{array}$ & Academic & $\begin{array}{l}\text { Laos, Cambodia, Viet Nam, } \\
\text { Thailand, Myanmar }\end{array}$ & $\begin{array}{l}\text { Environment and society, } \\
\text { public policy }\end{array}$ \\
\hline Royal University of Phnom Penh & Academic & Cambodia & Ecologist, climate change scientist \\
\hline $\begin{array}{c}\text { Can Tho University, College } \\
\text { of Economics }\end{array}$ & Academic & Viet Nam & Ecosystem service valuation \\
\hline $\begin{array}{l}\text { National University of Laos. } \\
\text { Faculty of Economics and } \\
\text { Business management }\end{array}$ & Academic & Laos & $\begin{array}{l}\text { Natural resource economics, } \\
\text { hydropower research }\end{array}$ \\
\hline Ubon Ratchathani University & Academic & Thailand & Fisheries \\
\hline $\begin{array}{c}\text { Yunnan University Institute of } \\
\text { International Rivers } \\
\text { and Eco-security }\end{array}$ & Academic & China, Laos, Cambodia, Myanmar & Hydropower, river health \\
\hline International rivers & INGO & $\begin{array}{l}\text { Laos, Cambodia, Viet Nam, } \\
\text { Thailand, Myanmar, China }\end{array}$ & NGO, river conservation \\
\hline IUCN Laos & INGO & Laos & Water, wetlands, biodiversity \\
\hline IUCN Regional office & INGO & $\begin{array}{c}\text { Laos, Cambodia, } \\
\text { Viet Nam, Thailand, Myanmar, } \\
\text { China }\end{array}$ & $\begin{array}{l}\text { Natural resources group, } \\
\text { wetlands biodiversity }\end{array}$ \\
\hline The Asia Foundation & NGO & Laos & Environment and development \\
\hline MIID & NGO & Myanmar & $\begin{array}{c}\text { Environment and social } \\
\text { development }\end{array}$ \\
\hline PACT THAILAND & INGO & $\begin{array}{l}\text { Laos, Cambodia, Viet Nam, } \\
\text { Thailand, Myanmar, China }\end{array}$ & $\begin{array}{c}\text { NGO environment } \\
\text { programmes, monitoring }\end{array}$ \\
\hline WWF & INGO & Laos & Biodiversity, fisheries \\
\hline WWF & INGO & Cambodia & Biodiversity conservation \\
\hline WWF- Greater Mekong & INGO & $\begin{array}{l}\text { Laos, Cambodia, Viet Nam, } \\
\text { Thailand, Myanmar, China }\end{array}$ & $\begin{array}{l}\text { Rivers, water risk, } \\
\text { geomorphology }\end{array}$ \\
\hline Wildlife Conservation Society & INGO & Cambodia & Conservation biodiversity \\
\hline Hydrotasmania & Hydropower developer & $\begin{array}{l}\text { Laos, Cambodia, } \\
\text { Viet Nam, Thailand }\end{array}$ & $\begin{array}{l}\text { Hydropower impacts, } \\
\text { sustainable hydropower }\end{array}$ \\
\hline Bourapha agroforestry & Forestry company & Laos & $\begin{array}{l}\text { Land, forest and water resources } \\
\text { spatial planning }\end{array}$ \\
\hline Consultant A & Consultancy & $\begin{array}{l}\text { Laos, Cambodia, Viet Nam, } \\
\text { Thailand, Myanmar }\end{array}$ & $\begin{array}{l}\text { Hydrology and } \\
\text { energy consultancy }\end{array}$ \\
\hline Consultant B & Consultant & Viet Nam & Water birds, migration \\
\hline Consultant $\mathrm{C}$ & Consultancy & Myanmar & $\begin{array}{l}\text { Hydrology, water } \\
\text { resources planning }\end{array}$ \\
\hline Consultant D & Consultancy & $\begin{array}{l}\text { Laos, Cambodia, } \\
\text { Viet Nam, Thailand }\end{array}$ & Hydrology, river health \\
\hline Consultant E & Consultancy & Laos & $\begin{array}{l}\text { Fisheries research } \\
\text { and development }\end{array}$ \\
\hline Consultant $\mathrm{F}$ & Consultancy & $\begin{array}{l}\text { Laos, Cambodia, Viet Nam, } \\
\text { Thailand, Myanmar }\end{array}$ & $\begin{array}{l}\text { Environment, ecology, } \\
\text { hydropower, sociology }\end{array}$ \\
\hline Consultant G & Consultant, & International & Spatial biodiversity planner \\
\hline
\end{tabular}


Table A1. Cont.

\begin{tabular}{ccc}
\hline Organisation & Type & Countries Worked in \\
\hline Consultant H & Consultant & $\begin{array}{c}\text { Laos, Cambodia, Viet Nam, } \\
\text { Thailand, Myanmar, China }\end{array}$ \\
\hline Consultant I & Consultant & $\begin{array}{c}\text { Laos, Cambodia, Viet Nam, } \\
\text { Thailand, Myanmar }\end{array}$ \\
\hline Consultant J & Consultant & $\begin{array}{c}\text { Laos, Cambodia, Viet Nam, } \\
\text { Thailand, Myanmar }\end{array}$ \\
\hline Consultant K & Consultant, & Laos \\
\hline Consultant L & Consultancy & $\begin{array}{c}\text { Laos, Cambodian, } \\
\text { Viet Nam, Thailand }\end{array}$ \\
\hline
\end{tabular}

Appendix B. Defining Ecological Importance for Mapping of Rivers in South East Asia-Semi-Structured Questionnaire

Appendix B.1. Introduction

This research aims to develop a framework or system of geospatial indicators for assessing the ecological importance of the rivers and their tributaries in South East Asia. It is being done as part of $\mathrm{PhD}$ in the School of Geosciences at the University of Edinburgh undertaken by Peter-John Meynell.

As the foundation for this research, we need to identify the potential uses and users of the framework for mapping ecological importance of rivers in South East Asia, and to establish their priorities for the different measures of ecological importance-the key ecosystem functions and services of rivers-and the pressures upon these functions and services. Secondly, we will try to identify the potential geospatial data that will enable us to measure and map these services and pressures and the sources of this data.

This survey of users and practitioners will enable us to prepare an analysis and justification for establishing such a framework and the priority ecosystem services to be considered. The second part of the survey will enable us to source relevant data and develop spatial analytical methods to develop the framework. A pictorial story map of the ecosystem services in the rivers of South East Asia is provided at https://arcg.is/1v4arm (accessed on 25 February 2019).

This questionnaire is directed at the potential users of such a framework, from government agencies, international and regional agencies, river basin and development planners, consultants, natural resource researchers and academics, and environmental and social development NGOs. It is divided into six questions and checklists:

1. About the respondent and their work,

2. Uses of a system of indicators for ecological importance of rivers,

3. Prioritising different ecosystem services of rivers to be included in the indicator framework,

4. Prioritising threats and pressures to indicate status and river health condition.

Suggestions for existing studies and monitoring programmes that can provide information and data for developing ecological indicators are encouraged.

The questionnaire will be conducted in face-to-face or skype interviews, allowing follow-up questions to be discussed. The answers to the questions will be taken as your personal opinions on the subject, based upon your experience and job, rather than as official policy statements of your agency. The interviews will be recorded, with your permission, so that recall of content may be facilitated. In the dissertation, the analysis will not include any personal attribution and any statements or quotes will be reported anonymously, or if these are contextualised, permission to use the statements would be sought from you. Appropriate permissions to use datasets both directly or analysed within the context of the ecological framework would be obtained. It is intended that the framework of ecological importance of rivers in South East Asia will be made freely accessible with interactive 
maps that will allow user selection of priority services. A briefing paper on the findings of the research will be provided to all respondents.

Appendix B.1.1. About the Respondent and Their Work

Name

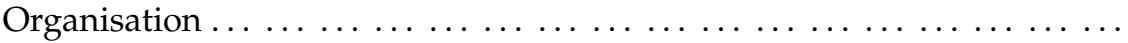

Department

Position

....

How long have you worked for this organisation/department?

..........

How long have you worked professionally on river-related issues?

...........................

In the tables below, please tick the appropriate response. You may tick several responses, and add additional comments in the spaces provided

1. In which South East Asian country/s and rivers do you work?

Table A2. Response table for South East Asian countries and rivers worked in.

\begin{tabular}{|c|c|c|c|c|}
\hline Country & Tick & River System & Tick & Comments \\
\hline Cambodia & & Red River & & \\
\hline China & & Lancang/Mekong & & \\
\hline Laos & & Chao Phraya & & \\
\hline Myanmar & & $\mathrm{Nu}$ /Salween/Thanlwin & & \\
\hline Thailand & & Ayeyarwady & & \\
\hline Viet Nam & & Chindwin & & \\
\hline Other (Please specify) & & Other (Please specify) & & \\
\hline
\end{tabular}

2. How would you best describe the organisation you work with?

Table A3. Response table to describe organization type.

\begin{tabular}{cc}
\hline Type of Organisation & Tick \\
\hline Government Ministry & \\
\hline River Basin Organisation & \\
\hline Research Institute & \\
\hline $\begin{array}{c}\text { Intergovernmental } \\
\text { organisation }\end{array}$ & \\
\hline United Nations agency & \\
\hline Development Bank & \\
\hline Development Partner & \\
\hline Private sector & \\
\hline Consultant & \\
\hline Legal and policy advisor & \\
\hline University & \\
\hline INGO & \\
\hline NGO/CSO & \\
\hline Media & \\
\hline Other (please specify) &
\end{tabular}


3. How would you best describe the jobs and sectors you work in?

Table A4. Response table to describe job type.

\begin{tabular}{cc}
\hline Type of Job & Tick \\
\hline River basin planning & $\begin{array}{c}\text { Please Describe the Focus } \\
\text { for Your Work }\end{array}$ \\
\hline Water resource management & \\
\hline Water law and regulations & \\
\hline Engineering and design & \\
\hline Environmental management & \\
\hline Knowledge management & \\
\hline Researcher & \\
\hline Development assistance \\
\hline wone of these fit, please describe your \\
\hline
\end{tabular}

4. Sector-river or river basin/water uses that you work in

Table A5. Response table to describe sectors worked in.

\begin{tabular}{cc}
\hline Sector & Tick \\
\hline Hydropower & $\begin{array}{c}\text { Please Provide Further } \\
\text { Details on the Sector }\end{array}$ \\
\hline Agriculture & \\
\hline Irrigation & \\
\hline Forestry & \\
\hline Capture fisheries & \\
\hline Aquaculture & \\
\hline Protected areas management & \\
\hline Domestic water supply & \\
\hline Industrial water supply & \\
\hline Waste water treatment & \\
\hline Nourism and recreation &
\end{tabular}

Appendix B.1.2. Uses of a System of Indicators for Ecological Importance of Rivers

5. Uses of a system for ecological importance of rivers

(1) Has the absence of a system for measuring and mapping ecological importance of rivers ever restricted your work? Yes/No/Don't Know

(2) Can you give any examples?

(3) How would you rate the usefulness of a system to map ecological importance of rivers in the following activities? 
Table A6. Response table to assess usefulness of Ecological Importance System of rivers.

\begin{tabular}{|c|c|c|c|c|c|}
\hline Usefulness of Ecological Importance System of Rivers & High & Medium & Low & Not Useful & Don't Know \\
\hline \multicolumn{6}{|l|}{ Preparation of river basin profiles } \\
\hline \multicolumn{6}{|l|}{ IWRM and Integrate River Basin Management studies } \\
\hline \multicolumn{6}{|l|}{ Providing biophysical evidence defining environmental assets } \\
\hline \multicolumn{6}{|l|}{ Understanding the ecological character and habitats of rivers } \\
\hline \multicolumn{6}{|l|}{$\begin{array}{l}\text { Identifying parts of rivers for protection because of their } \\
\text { ecological importance }\end{array}$} \\
\hline \multicolumn{6}{|l|}{$\begin{array}{l}\text { Identifying parts of rivers that may be impacted by } \\
\text { development and develop mitigation measures }\end{array}$} \\
\hline \multicolumn{6}{|l|}{ Fisheries management and regulation } \\
\hline \multicolumn{6}{|l|}{$\begin{array}{c}\text { Locating and planning hydropower, agriculture or } \\
\text { industrial infrastructure }\end{array}$} \\
\hline \multicolumn{6}{|l|}{$\begin{array}{l}\text { For assessing environmental and social impacts (EIA, Strategic } \\
\text { and cumulative impact studies }\end{array}$} \\
\hline \multicolumn{6}{|l|}{ Other examples (please specify) } \\
\hline Comments- & se give & mples & & & \\
\hline
\end{tabular}

Appendix B.1.3. Prioritising Different Ecosystem Services of Rivers to Be Included in the Indicator Framework

6. Ecosystem services provided by rivers

This section aims to identify the most important ecosystem services of rivers. Please rate the different ecosystem services that would be most useful to be included in the ecological importance indicator framework.

Table A7. Response table to assess importance of ecosystem services of rivers.

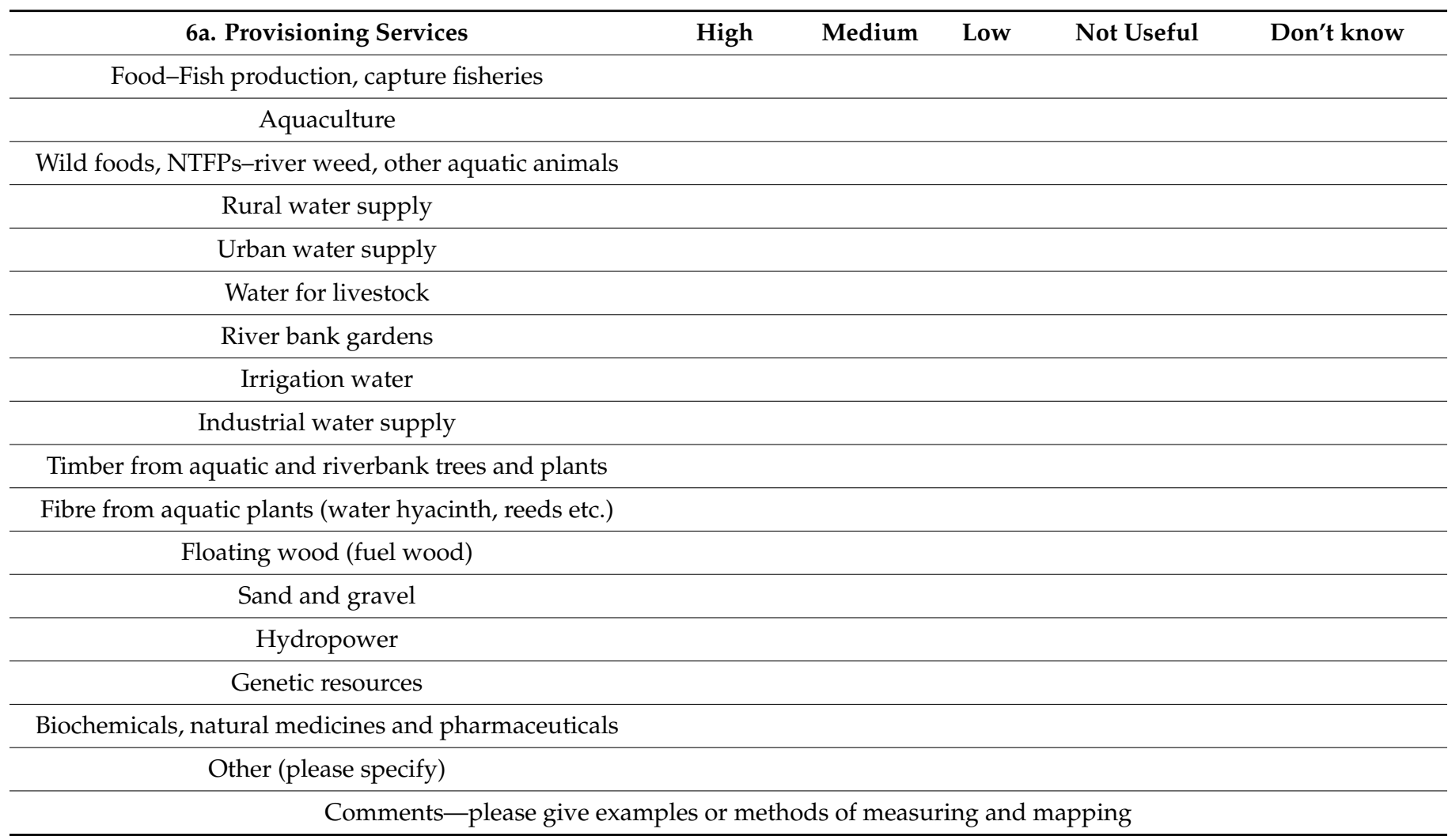


Table A7. Cont.

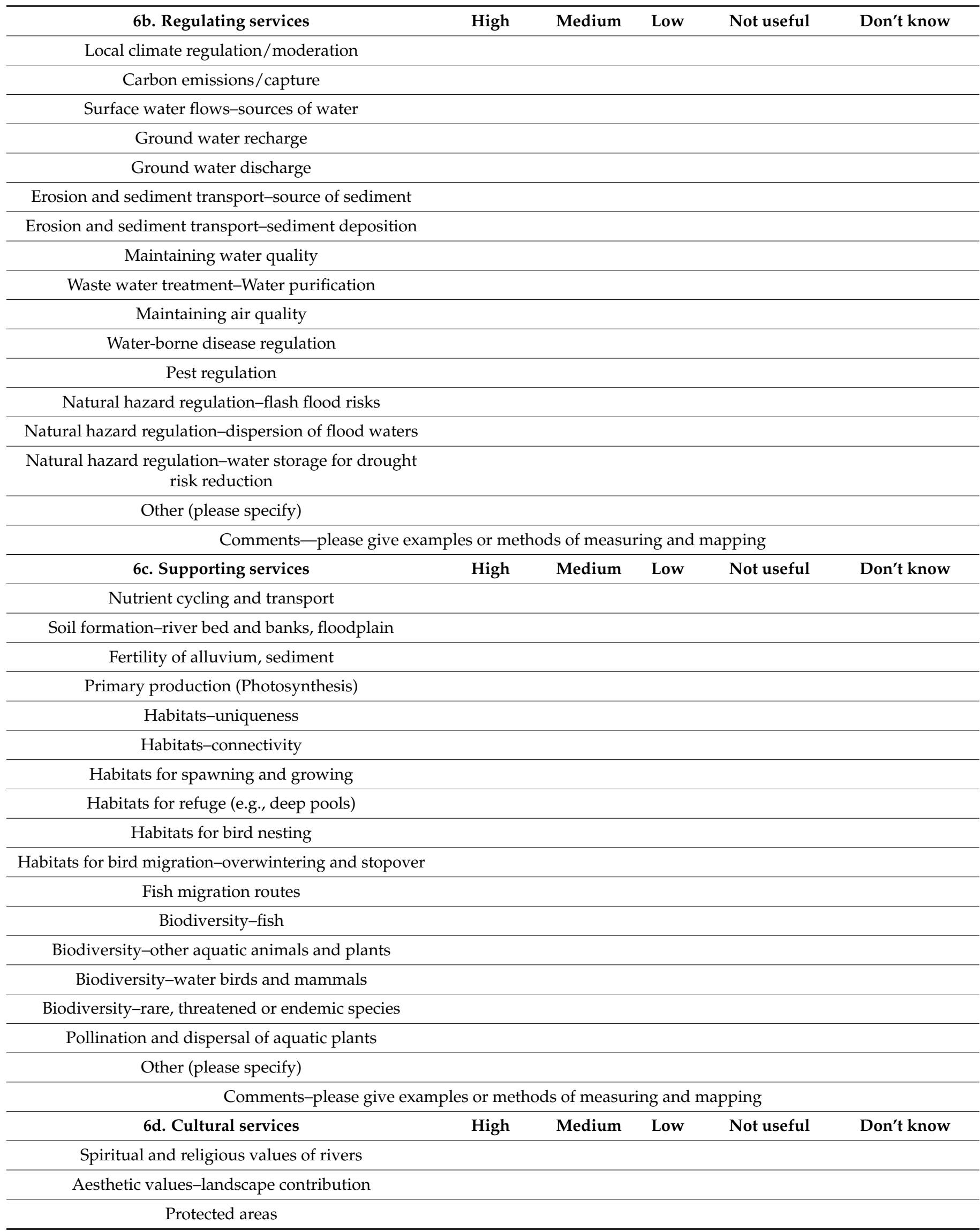


Table A7. Cont.

\begin{tabular}{c}
\hline Locational value-e.g., near confluences of river \\
\hline Cultural values-e.g., festivals, boat racing \\
\hline Transport and navigation \\
\hline Education and research \\
Recreation \\
\hline Ecotourism \\
\hline Political and administrative boundaries \\
Other (please specify) \\
Comments-please give examples or methods of measuring and mapping
\end{tabular}

Appendix B.1.4. Prioritising Threats and Pressures to Indicate Status and River Health Condition

\section{Status and river health condition}

The status or river health condition is becoming increasingly compromised by human activities. In the absence of comprehensive monitoring of the status and condition of rivers in South East Asia, an indication of the level of threat or pressure on each river reach may be used to predict probable condition. Please indicate the threats and pressures upon river environments that it will be useful to include in the ecological importance indicator framework.

Table A8. Response table to assess importance of threats and pressures on river systems.

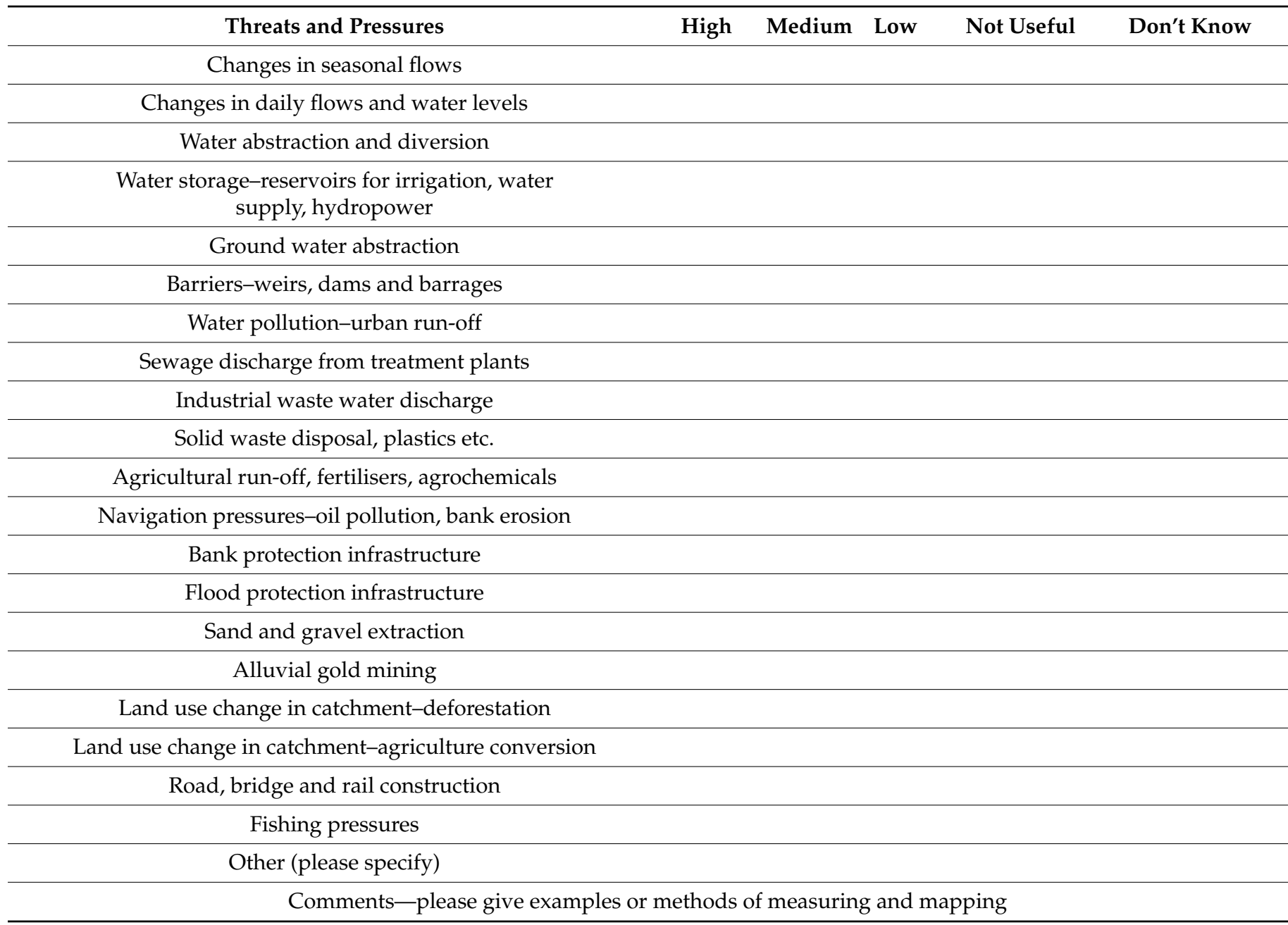




\section{Appendix C. Weighted Preference Scores for Different Uses of a River Ecological Importance Framework by Job Type and Sector}

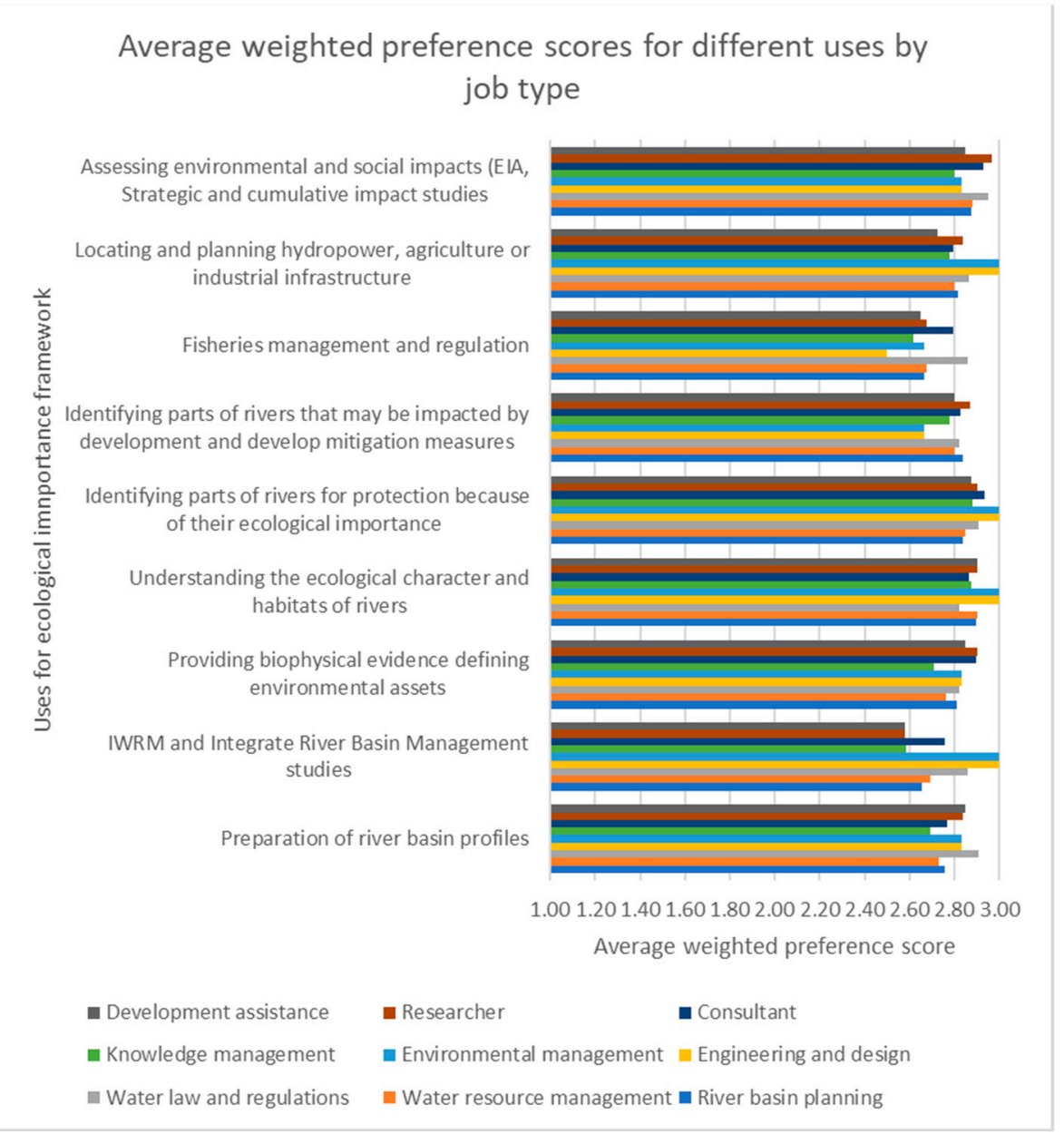

Figure A1. Average weighted preference scores for different uses by job type.

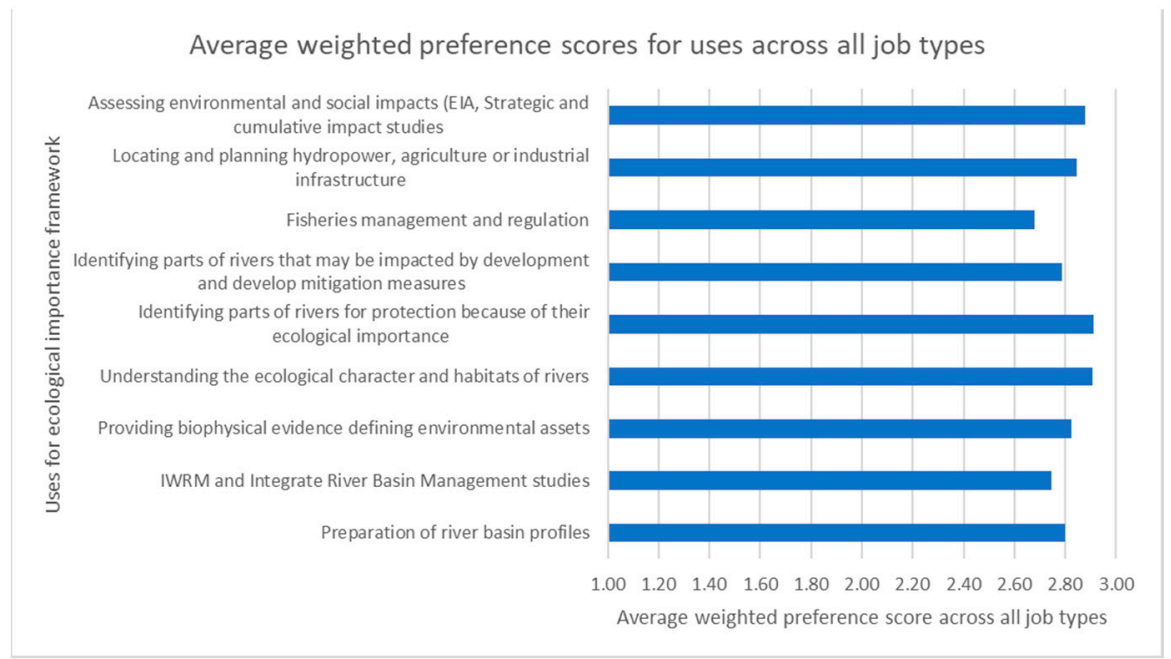

Figure A2. Average weighted preference scores for uses across all job types. 


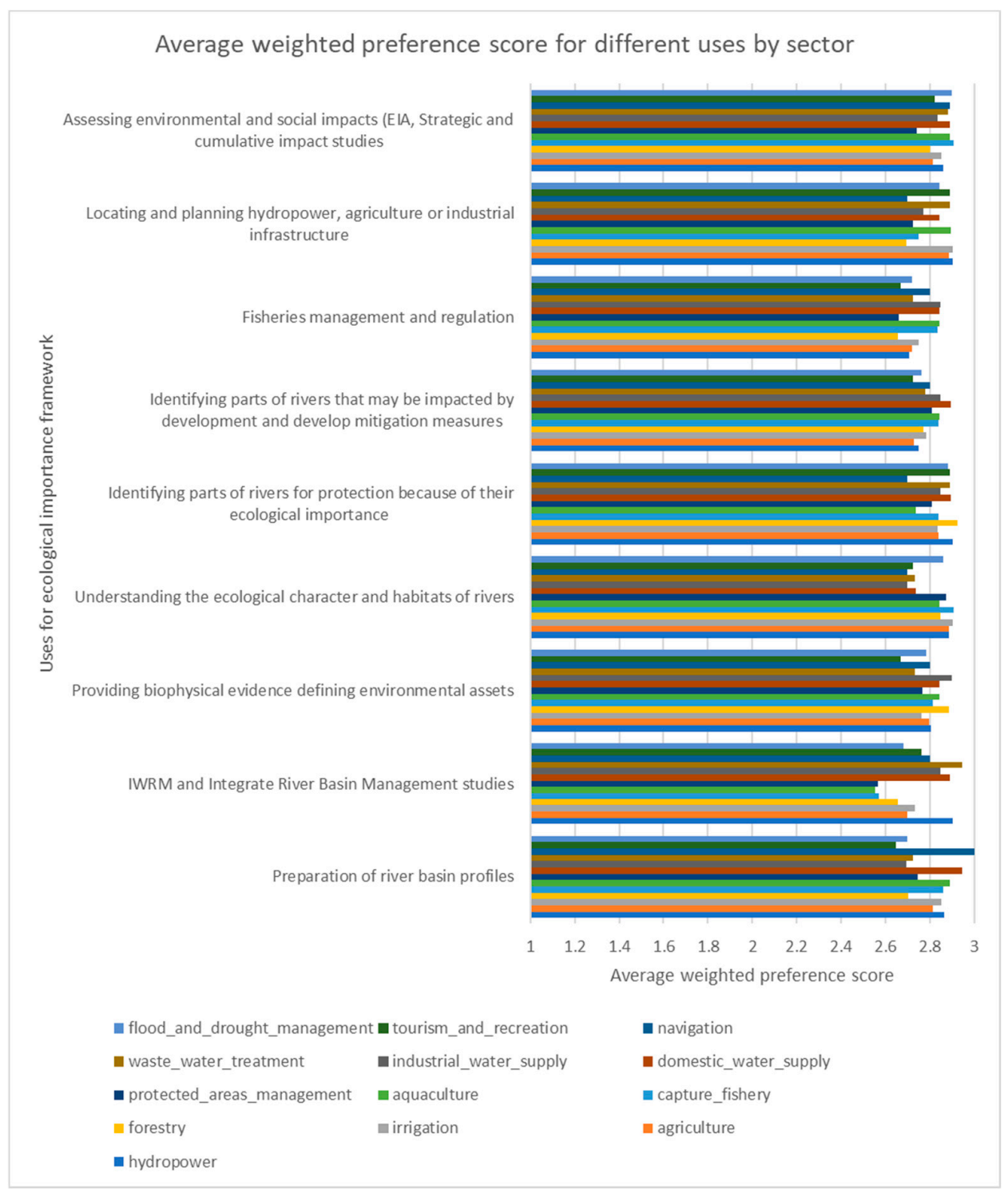

Figure A3. Average weighted preference scores for different uses by sector.

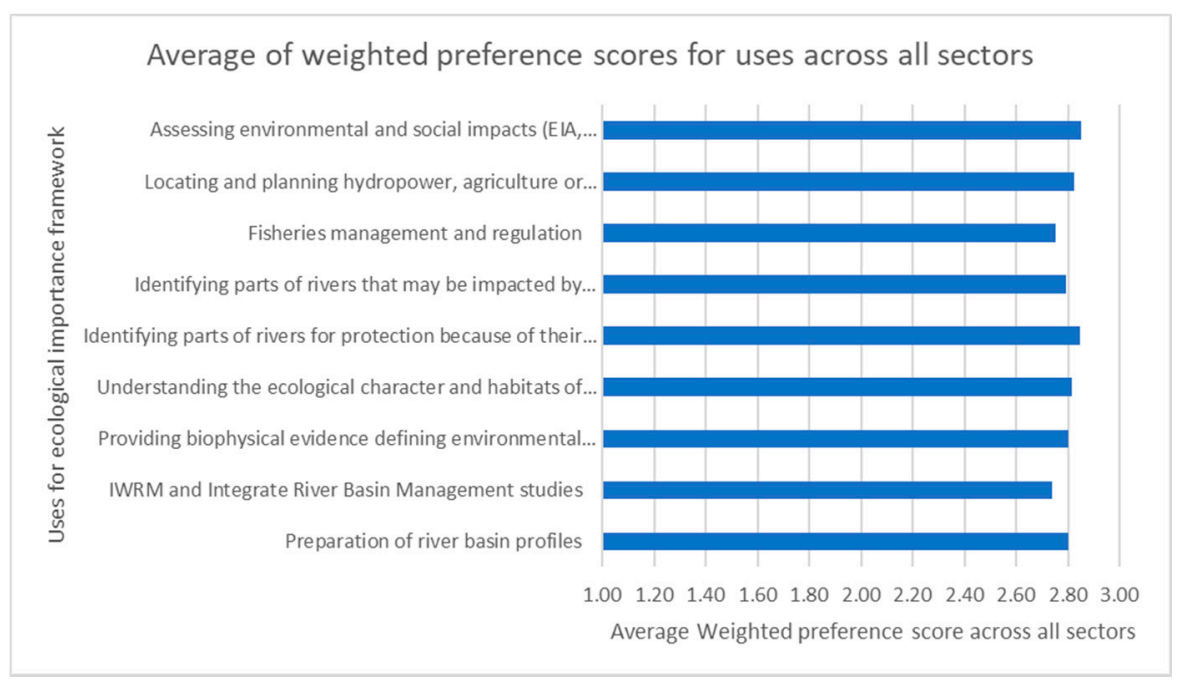

Figure A4. Average weighted preference scores for uses across all sectors. 


\section{References}

1. Ramsar Convention. State of the World's Wetlands and Their Services to People: A Compilation of Recent Analyses; Ramsar Convention Secretariat: Gland, Switzerland, 2015.

2. European Environmental Agency. European Waters Assessment of Status and Pressures 2018; Publications Office of the European Union: Luxembourg, 2018.

3. Gray, R. Third of Freshwater Fish Threatened with Extinction; The Telegraph: London, UK, 2011.

4. Grill, G.; Lehner, B.; Thieme, M.; Geenen, B.; Tickner, D.; Antonelli, F.; Zarfl, C. Mapping the world's free-flowing rivers. Nature 2019, 569, 215-221. [CrossRef] [PubMed]

5. Arfanuzzaman, M.D.; Dahiya, B. Sustainable urbanization in Southeast Asia and beyond: Challenges of population growth, land use change, and environmental health. Growth Chang. 2019, 50, 725-744. [CrossRef]

6. ADB. Key Indicators Database. Available online: https:/ / kidb.adb.org/kidb/ (accessed on 2 March 2021).

7. IFC. Strategic Environmental Assessment of Hydropower in Myanmar; International Finance Corporation: Yangon, Myanmar, 2018.

8. IFC. Cumulative Impact Assessment of the Myitnge River Basin; IFC: Yangon, Myanmar, 2019.

9. IFC. Cumulative Impact Assessment and Management of Renewable Energy Development in the Sekong River Basin, Lao PDR; International Finance Corporation: Washington, DC, USA, 2019.

10. UN-Water. 2020: Summary Progress Update 2021-SDG 6-Water and Sanitation for All; UN-Water: Geneva, Switzerland, 2021.

11. MRC. State of the Basin Report 2019; Mekong River Commission: Vientiane, Lao PDR, 2019; p. 225.

12. Sendzimir, J.; Schmutz, S. Riverine Ecosystem Management. In Science for Governing Towards a Sustainable Future, 8th ed.; Schmutz, S., Sendzimir, J., Eds.; Springer International Publishing AG part of Springer Nature: Cham, Switzerland, 2018. [CrossRef]

13. European Commission. Common Implementation Strategy for the Water Framework Directive (2000/60/EC): Guidance Document No 13. Overall Approach to the Classification of Ecological Status and Ecological Potential; European Commission: Brussels, Belgium, 2005.

14. DPIPWE. Summary of the CFEV Assessment Framework. v1.3. Conservation of Freshwater Ecosystem Values Program; Department of Primary Industries, Parks, Water and Environment: Hobart, Australia, 2014.

15. Nel, J.; Colvin, C.; Le Maitre, D.C.; Smith, J.; Haines, I. Defining South Africa's Water Source Areas; WWF-World Wide Fund for Nature: Cape Town, South Africa, 2013.

16. Nel, J.L.; Driver, A.; Strydom, W.F.; Maherry, A.; Petersen, C.; Hill, L.; Roux, D.J.; Nienaber, S.; van Deventer, H.; Swartz, E.; et al. Atlas of Freshwater Ecosystem Priority Areas in South Africa: Maps to Support Sustainable Development of Water Resources; Water Research Commission: Gezina, South Africa, 2011.

17. Böck, K.; Polt, R.; Schülting, L. Ecosystem Services in River Landscapes. In Riverine Ecosystem Management; Schmutz, S., Sendzimir, J., Eds.; Springer: Cham, Switzerland, 2018; Volume 8, pp. 409-434.

18. Bouma, J.A.; van Beukering, P.J.H. Ecosystem services: From concept to practice. In Ecosystem Services. From Concept to Practice; Bouma, J.A., van Beukering, P.J.H., Eds.; Cambridge University Press: Cambridge, UK, 2015; pp. 3-21.

19. Schmeier, S.; Vogel, B. Ensuring Long-Term Cooperation Over Transboundary Water Resources Through Joint River Basin Management. In Riverine Ecosystem Management; Schmutz, S., Sendzimir, J., Eds.; Springer: Cham, Switzerland, 2018. [CrossRef]

20. Thu, H.N.; Wehn, U. Data sharing in international transboundary contexts: The Viet Namese perspective on data sharing in the Lower Mekong Basin. J. Hydrol. 2016, 536, 351-364. [CrossRef]

21. MRC. Strategic Plan 2016-2020; Mekong River Commission: Vientiane, Lao PDR, 2016.

22. MRC. The Integrated Water Resources Management-Based Basin Development Strategy for the Lower Mekong Basin 2021-2030 and the MRC Strategic Plan 2021-2025; Mekong River Commission: Vientiane, Laos, 2021.

23. MRC. Report on the 2017 Biomonitoring Survey of the Lower Mekong River and Selected Tributaries; Mekong River Commission: Vientiane, Lao PDR, 2019; p. 102.

24. MRC. 2017 Lower Mekong Regional Water Quality Monitoring Report; Mekong River Commission: Vientiane, Lao PDR, 2019.

25. Pham Tuan Phan (MRC CEO). The Mekong River Commission is Striking a Balance Between Development and Protection of the Mekong River. Available online: https:/ / www.mrcmekong.org/news-and-events/news/the-mekong-river-commission-isstriking-a-balance-between-development-and-protection-of-the-mekong-river (accessed on 2 March 2021).

26. HIC. Ayeyarwady State of the Basin Assessment (SOBA) 2017: Synthesis Report; Hydro-Informatics Centre: Yangon, Myanmar, 2017.

27. Salween University Network. In Proceedings of the Role of Research for a sustainable Salween River, Yangon, Myanmar, 26-27 February 2018.

28. Molle, F; Hoanh, C.T. Implementing integrated river basin management in the Red River Basin, Viet Nam: A solution looking for a problem? Water Policy 2011, 13, 518-534. [CrossRef]

29. MRC. Mekong River Basin Indicator Framework; The Mekong River Commission: Vientiane, Lao PDR, 2019 ; p. 30.

30. Millennium Ecosystem Assessment. Ecosystems and Human Well-Being: Wetlands and Water Synthesis; World Resources Institute: Washington, DC, USA, 2005.

31. CGIAR-WLE, Research Program on Water, Land and Ecosystems (WLE). Ecosystem Services and Resilience Framework; International Water Management Institute (IWMI): Colombo, Sri Lanka, 2014; p. 46.

32. CGIAR-WLE, Research Program on Water, Land and Ecosystems (WLE). On Spatially Distributed Hydrological Ecosystem Services-Bridging the Quantitative Information Gap Using Remote Sensing and Hydrological Models; FutureWater: Wageningen, The Netherlands, 2017. 
33. ADB. Thailand National Environmental Performance Assessment (EPA) Report; Asian Development Bank, Environmental Operations Centre: Bangkok, Thailand, 2007.

34. ADB. Lao PDR National Environmental Performance Assessment (EPA) Report; Asian Development Bank, Environment Operations Centre: Bangkok, Thailand, 2007.

35. ADB. Greater Mekong Sub-Region, Environmental Performance Assessment 2006-2016; Asian Development Bank, Environment Operations Centre: Bangkok, Thailand, 2018.

36. Brunner, J.; Carew-Reid, J.; Glemet, R.; McCartney, M.; Riddell, P. Measuring, Understanding and Adapting to Nexus Trade-Offs in the Sekong, Sesan and Srepok Transboundary River Basins; IUCN: Viet Nam Country Office: Ha Noi, Viet Nam, $2019 ;$ p. Viii +70.

37. Flammini, A.P.M.; Pluschke, L.; Dubois, O. Walking the Nexus Talk: Assessing the Water-Energy-Food Nexus in the Context of the Sustainable Energy for All Initiative; Climate, Energy and Tenure Division (NRC), Food and Agriculture Organization of the United Nations: Rome, Italy, 2014.

38. MRC. State of the Basin Report 2018; Mekong River Commission: Vientiane, Laos PDR, 2019.

39. Zeiringer, B.S.; Seliger, C.; Greimel, F.; Schmutz, S. River Hydrology, Flow Alteration and Environmental Flow. In Riverine Ecosystem Management; Schmutz, S., Sendzimir, J., Eds.; Springer: Cham, Switzerland, 2018; pp. 67-89. [CrossRef]

40. King, J.; Brown, C. Environmental flows: Striking the balance between development and resource protection. Ecol. Soc. 2006, 11, 26. [CrossRef]

41. MRC. The Council Study: Study on the Sustainable Management and Development of the Mekong River, Including Impacts of Mainstream Hydropower Projects; Biological Resource Assessment Mekong River Commission: Vientiane, Laos PDR, 2017 ; p. 697.

42. Knight, S.D.; Danks, F.; Burgess, N. Mapping Ecosystem Services; United Nations Environment Programme World Conservation Monitoring Centre (UNEP-WCMC): Cambridge, UK, 2015.

43. Nahuelhual, L.C.; Carmona, A.; Lozada, P.; Jaramillo, A.; Aguayo, M. Mapping recreation and ecotourism as a cultural ecosystem service: An application at the local level in Southern Chile. Appl. Geogr. 2013, 40, 71-82. [CrossRef]

44. Popelka, S.J.S.; Smith, L.C. Rivers as political borders: A new subnational geospatial dataset. Water Policy 2020, $22,293-312$. [CrossRef]

45. IUCN, N.A.F.R.I., National University of Lao PDR, SNV Netherlands Development Organisation, NL. Non-Timber Forest Products in the Lao PDR: A Manual of 100 Commercial and Traditional Products; IUCN Laos: Vientiane, Laos, 2007.

46. Jetzer, C. River Spirits in the Nu River valley Yunnan, Southwest China; University of Oxford: Oxford, UK, 2014.

47. Chen, H. Sustainable Development in China's Decision Making on Large Dams: A case study of the Nu River Basin; Uppsala University: Uppsala, Sweden, 2013.

48. Allen, D.J.; Smith, K.G.; Darwall, W.R.T. The Status and Distribution of Freshwater Biodiversity in Indo-Burma; IUCN: Cambridge, UK; Gland, Switzerland, 2012; p. x+158.

49. ICEM. MRC Strategic Environmental Assessment (SEA) of Hydropower on the Mekong Mainstream: Summary of the Final Report; International Centre for Environmental Management: Hanoi, Viet Nam, 2010.

50. IFC. Strategic Environmental Assessment of the Myanmar Hydropower Sector-Final Report; International Finance Corporation: Washington, DC, USA, 2017.

51. DWIR, DHI. Development of the Ayeyarwady Decision Support System and Basin Master Plan-Scenario Formulation and Assessment Methodology; Directorate of Water Resources and Improvement of River Systems: Yangon, Myanmar, 2019.

52. Dallaire, C.O. A multidisciplinary framework to derive global river reach classifications. Environ. Res. Lett. 2019, 14, 024003. [CrossRef]

53. Lehner, B.; Verdin, K.; Jarvis, A. New global hydrograhy derived from spaceborne elevation data. EOS Trans. Am. Geophys. Union 2008, 89, 93-94. [CrossRef]

54. Linke, S.; Lehner, B.; Ouellet Dallaire, C. Global hydro-environmental subbasin and river reach characteristics at high spatial resolution. Sci. Data 2019, 6, 283. [CrossRef] [PubMed]

55. Lehner, B.; Ouellet Dallaire, C. River Reach Classification for the Greater Mekong Region. Report for WWF Greater Mekong; WWF Greater Mekong: Vientiane, Lao PDR, 2014.

56. IFC. Nam Ou River Basin Profile-Summary Document. Environmental E Social Characteristics of a Key River Basin in Lao PDR; International Finance Corporation: Washington, DC, USA, 2017.

57. Olson, D.M.; Dinerstein, E.; Wikramanayake, E.D.; Burgess, N.D.; Powell, G.V.N.; Underwood, E.C.; D’Amico, J.A.; Itoua, I.; Strand, H.E.; Morrison, J.C.; et al. Terrestrial ecoregions of the world: A new map of life on Earth. Bioscience 2001, 51, 933-938. [CrossRef]

58. Abell, R.; Thieme, M.; Revenga, C.; Bryer, M.; Kottelat, M.; Bogutskaya, N.; Coad, B.; Mandrak, N.; Contreras-Balderas, S.; Bussing, W.; et al. Freshwater ecoregions of the world: A new map of biogeographic units for freshwater biodiversity conservation. BioScience 2008, 58, 403-414. [CrossRef]

59. Finlayson, C.M.; Begg, G.W.; Howes, J.; Davies, J.; Tagi, K.; Lowry, J. A Manual for an Inventory of Asian Wetlands: Version 1.0; Wetlands International Malaysia: Kuala Lumpur, Malaysia, 2002.

60. Murray, N.J.; Keith, D.A.; Tizard, R.; Duncan, A.; Htut, W.T.; Oo, A.H.; Ya, K.Z.; Grantham, M. Threatened Ecosystems of Myanmar: An IUCN Red List of Ecosystems Assessment. Version 1; Wildlife Conservation Society: Yangon, Myanmar, 2020.

61. Bao, P.N.; Mitra, B.K.; Kuyama, T. Integrated Approach for Sustainable Hydropower Development in the Mekong River Basin. Environ. Nat. Resour. Res. 2017, 7, 60. [CrossRef] 
62. MRC. Basin-Wide Assessment of Climate Change Impacts on Hydropower Production. Final Report; Mekong River Commission: Vientiane, Laos, 2018.

63. Hortle, K.G.; Bamrungrach, P. Fisheries Habitat and Yield in the Lower Mekong Basin; Mekong River Commission: Phnom Penh, Cambodia, 2015.

64. Hortle, K.G. Consumption and the Yield of Fish and Other Aquatic Animals from the Lower Mekong Basin; Mekong River Commission: Vientiane, Laos, 2007; p. 87.

65. Chheng, P.; Un, S.; Tress, J.; Simpson, V.; Sieu, C. Fish Productivity by Aquatic Habitat and Estimated Fish Production in Cambodia Inland Fisheries Research and Development Institute(Fisheries Administration) and WorldFish: Phnom Penh, Cambodia, 2016; p. 23.

66. Dugan, P.J.; Barlow, C.; Agostinho, A.A.; Baran, E.; Cada, G.F.; Chen, D.; Cowx, I.G.; Ferguson, J.W.; Jutagate, T.; Mallen-Cooper, M.; et al. Fish Migration, Dams, and Loss of Ecosystem Services in the Mekong Basin. AMBIO 2010, 39, 344-348. [CrossRef] [PubMed]

67. Soe, K.M.; Baran, E.; Grantham, R.; Tezzo, X.; Johnstone, G. Myanmar Inland Fisheries and Aquaculture: A Decade in Review; Australian Centre for International Agricultural Research, WorldFish: Canberra, Australia; Yangon, Myanmar, $2020 ;$ p. 93.

68. Baran, E.; Win, K.K.; Zi, Z.W.; Khin, M.N.; Ghataure, G.; Khin, M.S. Fisheries in the Ayeyarwady Basin; National Water Resources Committee (NWRC): Yangon, Myanmar, 2017.

69. Yu, X.; He, D.; Phousavanh, P. Balancing River Health and Hydropower Requirements in the Lancang River Basin; Springer Nature Singapore Pte Ltd.: Singapore, 2019. [CrossRef]

70. Souter, N.J.; Shaad, K.; Vollmer, D.; Regan, H.M.; Farrell, T.A.; Arnaiz, M.; Meynell, P.-J.; Cochrane, T.A.; Arias, M.E.; Piman, T.; et al. Using the Freshwater Health Index to Assess Hydropower Development Scenarios in the Sesan, Srepok and Sekong River Basin. Water 2020, 12, 788. [CrossRef]

71. Vollmer, D.S.K.; Souter, N.J.; Farrell, T.; Dudgeon, D.; Sullivan, C.A.; Fauconnier, I.; MacDonald, G.M.; McCartney, M.P.; Power, A.G.; McNally, A.; et al. Integrating the social, hydrological and ecological dimensions of freshwater health: The Freshwater Health Index. Sci. Total Environ. 2018, 627, 304-313. [CrossRef] [PubMed] 